University of New Hampshire

University of New Hampshire Scholars' Repository

Law Faculty Scholarship

University of New Hampshire - Franklin Pierce

School of Law

$1-1-2013$

\title{
Constitutional Remedies \& Public Interest Balancing
}

John M. Greabe

University of New Hampshire School of Law

Follow this and additional works at: https://scholars.unh.edu/law_facpub

Part of the Constitutional Law Commons, and the Public Law and Legal Theory Commons

\section{Comments}

Abstract available at http://ssrn.com/abstract=2131761

\section{Recommended Citation}

John M. Greabe, "Constitutional Remedies \& Public Interest Balancing," 21 WM. \& MARY BILL RTS. J. 857 (2013).

This Article is brought to you for free and open access by the University of New Hampshire - Franklin Pierce School of Law at University of New Hampshire Scholars' Repository. It has been accepted for inclusion in Law Faculty Scholarship by an authorized administrator of University of New Hampshire Scholars' Repository. For more information, please contact sue.zago@law.unh.edu. 


\title{
CONSTITUTIONAL REMEDIES AND PUBLIC INTEREST BALANCING
}

\author{
John M. Greabe*
}

\begin{abstract}
The conventional account of our remedial tradition recognizes that courts may engage in discretionary public interest balancing to withhold the specific remedies typically administered in equity. But it generally does not acknowledge that courts possess the same power with respect to the substitutionary remedies usually provided at law. The conventional account has things backwards when it comes to constitutional remedies. The modern Supreme Court frequently requires the withholding of substitutionary constitutional relief under doctrines developed to protect the perceived public interest. Yet it has treated specific relief to remedy ongoing or imminent invasions of rights as routine, at least when the underlying claim is justiciable and subject to neither a judicial federalism doctrine nor statutory preclusion.

This paper details the reversal of the conventional account of remedial power and advances a two-part hypothesis that the Court's behavior traces an appropriate constitutional boundary. The hypothesis is as follows. First, substitutionary constitutional remedies, while integral to the proper functioning of our constitutional order, are individually contingent and susceptible of legislative or judicial expansion, contraction, or replacement as the perceived public interest dictates. But second, specific relief must be available for justiciable and meritorious claims of constitutional right to which neither a judicial federalism nor a statutory diversion doctrine applies, and an effective constitutional remedy ultimately must be available even in these exceptional cases.
\end{abstract}

\section{INTRODUCTION}

The conventional account of our remedial tradition recognizes that courts may engage in discretionary public interest balancing to withhold the specific remedies typically administered in equity. ${ }^{1}$ But it generally does not acknowledge that courts

* Professor, University of New Hampshire School of Law. For helpful comments and suggestions on earlier versions of this Article, I would like to thank Susan Bandes, Calvin Massey, Margaret Sova McCabe, Jack Preis, Mitch Simon, Howard Wasserman, and participants in the 2012 Junior Faculty Federal Courts Workshop held at Florida International Law School. I also thank the editors and staff of the William \& Mary Bill of Rights Journal for their excellent work in improving this paper.

1 I use the term "public interest balancing" to describe the practice of withholding relief, even in the face of an invasion of rights, on the ground that the remedy sought would adversely affect the public interest. Public interest balancing is an explicit part of the calculus 
possess the same power with respect to the substitutionary remedies ${ }^{2}$ usually available at law. ${ }^{3}$ The conventional account has things backwards when it comes to constitutional remedies. ${ }^{4}$ The modern Supreme Court frequently requires the withholding of substitutionary constitutional relief under doctrines-qualified immunity, ${ }^{5}$ exceptions to the exclusionary rule, ${ }^{6}$ harmless error rules, ${ }^{7}$ the unavailability of most "new law" on collateral review ${ }^{8}$ - developed to protect the perceived public interest. ${ }^{9} Y$ Yet it has treated specific relief to remedy ongoing or imminent invasions of rights as routine, ${ }^{10}$ at least

courts apply in deciding whether to issue a preliminary injunction. See, e.g., Winter v. Natural Res. Def. Council, Inc., 129 S. Ct. 365, 374 (2008). But it also is an acknowledged component of a court's equitable discretion at the final judgment stage. See, e.g., Salazar v. Buono, $130 \mathrm{~S}$. Ct. 1803, 1816 (2010); Weinberger v. Romero-Barcelo, 456 U.S. 305, 311-13(1982); Hecht Co. v. Bowles, 321 U.S. 321, 327-30 (1944); United States ex rel. Greathouse v. Dern, 289 U.S. 352, 360-61 (1933); see also DOUGLAS LAYCOCK, THE DEATH OF THE IRREPARABLE INJURY RULE 160-61 (1991); 11 A CHARLES ALAN WRIGHT ET AL., FEDERAL PRACTICE AND Procedure § 2942 (2d ed. 1995 \& Supp. 2012).

${ }^{2}$ For reasons explained in Part II, I use the functional terms "specific" and "substitutionary" rather than the historical terms "equitable" and "legal" to classify constitutional remedies. Although "most equitable remedies are specific" and "most legal remedies are substitutionary ... there are . . . exceptions in both directions" that make the equity/law distinction an unfit proxy for the specific/substitutionary distinction. DOUGLAS LAYCOCK, MODERN AMERICAN REMEDIES 6 (4th ed. 2010).

${ }^{3}$ An exception applies with respect to those legal remedies, such as mandamus, that are by their nature more like the specific remedies historically available from equity courts. See Dern, 289 U.S. at 359 ("Although the remedy by mandamus is at law, its allowance is controlled by equitable principles, and it may be refused for reasons comparable to those which would lead a court of equity, in the exercise of a sound discretion, to withhold its protection of an undoubted legal right." (citations omitted)).

${ }^{4}$ The conventional account of our remedial tradition has been persuasively criticized on other grounds as well. See LAYCOCK, supra note 1, at 3-7 (summarizing his book's argument that, despite traditional understandings, the American legal system does not and has not given primacy to substitutionary remedies over specific remedies).

5 See Harlow v. Fitzgerald, 457 U.S. 800 (1982).

${ }^{6} \mathrm{See}$, e.g., United States v. Leon, 468 U.S. 897 (1984).

7 See Brecht v. Abrahamson, 507 U.S. 619 (1993); Chapman v. California, 386 U.S. 18 (1967).

8 See Teague v. Lane, 489 U.S. 288 (1989).

9 In developing doctrines that require lower courts to withhold constitutional remedies, the Supreme Court has exercised both a normative discretion to withhold remedies and an allocative discretion to cabin lower court discretion. See David L. Shapiro, Jurisdiction and Discretion, 60 N.Y.U. L. REV. 543, 545-47 (1985) (explaining the range of existing judicial discretion). But a lower court's decision to withhold a remedy because of public interest balancing is a decision to withhold a remedy because of public interest balancing, regardless of whether it derives from an exercise of unconstrained equitable discretion or pursuant to a precedential dictate from a higher court. $C f$. supra note 1 (describing public interest balancing as a component of a court's equitable discretion).

10 See Richard H. Fallon, JR. ET Al., Hart and Wechsler's The Federal Courts AND THE FEDERAL SYSTEM 724-25 (6th ed. 2009) [hereinafter FALLON ET AL., HART AND 
when the underlying claim is justiciable and subject to neither a judicial federalism doctrine $^{11}$ nor statutory preclusion. ${ }^{12}$

This paper details the reversal of the conventional account of remedial power and suggests that its formal recognition could help to advance the debate over constitutionally necessary remedies. This debate ranges between those who, on one end of the spectrum, understand the maxim "where there is a right, there is a remedy"13 to be a binding norm, ${ }^{14}$ and those who, on the other, conclude from their examination of history that the only mandatory remedy for a constitutional violation is nullification of a void enactment. ${ }^{15}$ Between these positions lies the influential view ventured by Professors Richard Fallon, Jr., and Daniel Meltzer. ${ }^{16}$ Fallon and Meltzer's argument, while normative in its aspirations, is largely descriptive; it seeks to rationalize "the doctrines and practices that have traditionally comprised the law of constitutional remedies." ${ }^{17}$ So what do these doctrines and practices tell us, according to Fallon and Meltzer? First, there should be a strong but not always unyielding presumption in

WECHSLER] (citing Laycock, supra note 1, at 3-7, 41-42, 196, 223); Richard H. Fallon, Jr., Jurisdiction-Stripping Reconsidered, 96 VA. L. REV. 1043, 1112-13 (2010) [hereinafter Fallon, Jurisdiction-Stripping]; John C. Jeffries, Jr. \& George A. Rutherglen, Structural Reform Revisited, 95 CALIF. L. REV. 1387, 1395 (2007); see also Abram Chayes, The Role of the Judge in Public Law Litigation, 89 HARV. L. REV. 1281, 1292 (1976) ("It is perhaps too soon to reverse the traditional maxim to read that money damages will be awarded only when no suitable form of specific relief can be devised. But surely, the old sense of equitable remedies as 'extraordinary' has faded."); infra Part III.B.

1 See FALlON ET AL., HART AND WeCHSLER, supra note 10, at 1013-1152, 1311-54 (analyzing statutory and judicially developed limitations on district court jurisdiction or its exercise, such as exhaustion doctrines, abstention doctrines, and other doctrines of equity, comity, and federalism); see also infra Part III.B.1.

12 See, e.g., FALLON ET AL., HART AND WECHSLER, supra note 10, at 320 (discussing congressional apportionment of jurisdiction among federal courts); id. at 970-72 (discussing statutory preclusion and diversion of civil rights claims); see also infra Part III.B.2.

13 The original Latin phrase is "Ubi jus, ibi remedium." BLACK's LAW DiCTIONARY 1520 (6th ed. 1990); see also Marbury v. Madison, 5 U.S. (1 Cranch) 137, 147 (1803) ("It is a settled and invariable principle, that every right, when withheld, must have a remedy, and every injury its proper redress.").

${ }_{14}$ Among those who have so argued are Akhil Reed Amar, Of Sovereignty and Federalism, 96 Y ALE L.J. 1425 (1987); Susan Bandes, Reinventing Bivens: The Self-Executing Constitution, 68 S. CAL. L. REV. 289 (1995); Donald H. Zeigler, Rights Require Remedies: A New Approach to the Enforcement of Rights in the Federal Courts, 38 HASTINGS L.J. 665 (1987).

15 See John Harrison, Jurisdiction, Congressional Power, and Constitutional Remedies, 86 GEO. L.J. 2513 (1998).

${ }^{16}$ See Richard H. Fallon, Jr. \& Daniel J. Meltzer, New Law, Non-Retroactivity, and Constitutional Remedies, 104 HARV. L. REV. 1731 (1991).

${ }^{17} \mathrm{Id}$. at 1737 ("Our aim in adopting this approach, rather than developing a more purely normative theory, is partly to achieve enhanced clarity of doctrinal understanding; we hope to further comprehension of what courts have done and continue to do, and of the presuppositions that undergird their pattern of decisions."). 
favor of individually effective relief for every constitutional violation. ${ }^{18}$ Second, there must exist a sufficient scheme of available remedies to ensure that constitutional rights do not become nullities, and that government officials remain answerable as a systemic matter to the demands of law. ${ }^{19}$

I adopt Fallon and Meltzer's methodology and, looking to the doctrines and practices that comprise the modern law of constitutional remedies, seek to draw lessons from the distinct ways in which the modern Supreme Court has treated substitutionary and specific constitutional remedies with respect to public interest balancing. Building from a functional account of the law of constitutional remedies, I advance a two-part hypothesis that the Court's behavior traces an appropriate constitutional boundary. The hypothesis is as follows. First, substitutionary constitutional remedies, while integral to the proper functioning of our constitutional order, are individually contingent and susceptible of legislative or judicial expansion, contraction, or replacement as the perceived public interest dictates. But second, specific relief must be available for justiciable and meritorious claims of constitutional right to which neither a judicial federalism nor a statutory diversion doctrine applies, and an effective constitutional remedy ultimately must be available even in these exceptional cases.

I have organized the paper in the following way. Part I covers some preliminary points about the premises and scope of my argument, and the method I employ to classify constitutional remedies. Part II provides an account of the range of recognized constitutional remedies that classifies in terms that are functional (specific or substitutionary) rather than historical (equitable or legal). Classifying constitutional remedies in functional rather than historical terms is conducive to both a defense and an understanding of the paper's foundational descriptive claim. Part III employs this classification to demonstrate that modern courts frequently apply doctrines grounded in public interest balancing to withhold substitutionary relief for wholly realized constitutional violations despite the fact that doing so leaves such violations entirely without a remedy. In contrast, when faced with claims for specific relief, courts do not invoke the public interest to withhold relief altogether. Part IV connects the described reality to the debate over constitutionally necessary remedies and hypothesizes that the different ways in which the modern Supreme Court has treated substitutionary and specific constitutional remedies with respect to public interest balancing reflects an appropriate sense of the constitutional necessity of each.

\section{PRELIMINARIES}

The topic of constitutional remedies is extraordinarily rich. It is the subject of an enormous and fascinating academic literature that exposes fault lines that run beneath, and sometimes jolt, our constitutional order. It will therefore come as no surprise that

18 See id. at 1787-91.

19 See id. 
the pedigree and legitimacy of many of the substitutionary and specific constitutional remedies described in Part II, and many of the remedy-limiting doctrines discussed in Part III, are subjects of profound and basic disagreements. These disagreements reflect fundamentally different ideas about the nature and scope of the "judicial Power" that Article III of the Constitution confers on the federal courts, and about how the federal courts ought to exercise that power. ${ }^{20}$

To illustrate, commentators have disagreed over whether the harmless error rule adopted in Chapman v. California ${ }^{21}$ is better conceptualized as being rooted in the Constitution itself $\mathrm{f}^{22}$ or as constituting an example of the constitutional "common law" whose existence and legitimacy Professor Henry Monaghan has famously identified and defended. ${ }^{23}$ Monaghan himself described the Chapman rule as an example of constitutional common law ${ }^{24}$-a body of sub-constitutional, judge-made doctrine that is "subject to [congressional] amendment, modification, or ... reversal"25 — and other commentators have agreed. ${ }^{26}$ But even if a consensus were to emerge that the Chapman rule is indeed an example of constitutional common law, the debate would merely proceed to an even more fundamental disagreement over the rule's legitimacy. For there are those who strongly believe that judges lack the authority to make constitutional common law and must confine themselves to elaborating "true" constitutional meaning. ${ }^{27}$ And it is difficult to defend Chapman as being a constitutionally compelled rule. ${ }^{28}$

${ }^{20}$ See U.S. CONST. art. III, § 1.

21386 U.S. 18 (1967). Chapman requires appellate courts to find that a constitutional trial error was harmless "beyond a reasonable doubt" in order to disregard the error. See id. at 24; see also infra Part III.A.3.

22 See Steven H. Goldberg, Harmless Error: Constitutional Sneak Thief, 71 J. CRIM. L. \& CRIMINOLOGY 421, 424 n.31 (1980) (referring to the Chapman rule as a "constitutional judgment").

${ }_{23}$ See Henry P. Monaghan, The Supreme Court, 1974 Term-Forward: Constitutional Common Law, 89 HARV. L. REV. 1, 2-3 (1975) (describing constitutional common law as a "substructure of substantive, procedural, and remedial rules drawing their inspiration and authority from, but not required by, various constitutional provisions").

${ }^{24}$ See Henry P. Monaghan, Harmless Error and the Valid Rule Requirement, 1989 SUP. CT. REV. 195, 200 n.30 (citing Monaghan, supra note 23, at 21).

${ }^{25}$ See Monaghan, supra note 23, at 3.

${ }_{26}$ See, e.g., Daniel J. Meltzer, Harmless Error and Constitutional Remedies, 61 U. CHI. L. REv. 1, 26-29 (1994); Craig Goldblatt, Comment, Harmless Error as Constitutional Common Law: Congress's Power to Reverse Arizona v. Fulminante, 60 U. CHI. L. REV. 985, 1005-12 (1993).

${ }^{27}$ See, e.g., Thomas W. Merrill, The Common Law Powers of Federal Courts, 52 U.CHI. L. REV. 1, 58-59 (1985) (calling Monaghan's theory "constitutionally unprincipled"); Thomas S. Schrock \& Robert C. Welsh, Reconsidering the Constitutional Common Law, 91 HARV. L. REV. 1117 (1978). For a summary of the argument that remedies must issue from legislatures, see ERWIN CHEMERINSKY, FEDERAL JURISDICTION § 9.1.2, at 610-11 (6th ed. 2007).

${ }^{28}$ See Meltzer, supra note 26, at 5-18 (explaining the difficulties with viewing Chapman v. California, 386 U.S. 18 (1967), as constitutionally rooted in view of other established rules 
I acknowledge disagreements such as these. But I cannot express opinions on them, and defend those opinions, without turning this paper into a book. Therefore, I shall simply clarify at the outset three related points about my working premises and the paper's scope. First, I approach the problems addressed through the general law of remedies, which contains valuable lessons for the study of the more specific field of constitutional remedies. ${ }^{29}$ Second, I take as a given the legitimacy of broad judicial discretion in fashioning constitutional remedies, for reasons amply and ably elaborated by others. ${ }^{30} \mathrm{I}$ shall not repeat their arguments here except as is necessary to contextualize my own. Third, for reasons I shall explain in Part IV, I see the law of substitutionary constitutional remedies as being most helpfully conceived as a body of sub-constitutional common law subject to legislative and judicial alteration; by contrast, I see the law of specific constitutional remedies as being more firmly rooted in the Constitution itself. ${ }^{31}$

One additional point of initial clarification is also in order. In keeping with the paper's theme of function over form, I describe constitutional remedies in terms that emphasize the type of relief (functionally speaking) that they afford, and not in terms that focus attention on the particularized legal and equitable vehicles through which constitutional remedies historically have been provided. ${ }^{32}$ Thus, I do not afford separate

and doctrines); Goldblatt, supra note 26, at 1010-12 (explaining how the Court's reasoning in Brecht v. Abrahamson, 507 U.S. 619 (1993), negates the possibility of viewing Chapman as a constitutional rule).

${ }^{29} C f$. Fallon \& Meltzer, supra note 16, at 1764-67 (explaining the value of examining the topics of legal novelty and retroactivity within the framework of the law of remedies).

${ }^{30}$ See, e.g., Fallon, Jurisdiction-Stripping, supra note 10, at 1134-35; Fallon \& Meltzer, supra note 16, at 1779-91 (discussing the importance of the availability of constitutional remedies); Jeffries \& Rutherglen, supra note 10, at 1389-408 (discussing the development of constitutional remedies); Daniel J. Meltzer, Congress, Courts, and Constitutional Remedies, 86 GEO. L.J. 2537, 2549-65 (1998); Gene R. Nichol, Bivens, Chilicky, and Constitutional Damage Claims, 75 VA. L. REV. 1117, 1129-42 (1989) (explaining that fashioning constitutional remedies is a legitimate use of judicial power); Martin H. Redish, Federal Common Law, Political Legitimacy, and the Interpretive Process: An "Institutionalist" Perspective, $83 \mathrm{NW}$. U. L. REV. 761, 796-97 (1989) (recognizing judicial authority to protect basic constitutional interests). See generally Walter E. Dellinger, Of Rights and Remedies: The Constitution as a Sword, 85 HARV. L. REV. 1532 (1972) (analyzing the Court's role in enforcing constitutional guarantees); Monaghan, supra note 23 (recognizing remedial rules as part of constitutional common law).

${ }^{31}$ See infra Part IV. But cf. David H. Gans, Severability as Judicial Lawmaking, 76 GEO. WASH. L. REV. 639, 660 (2008) ("The law of constitutional remedies is almost entirely a matter of judge-made federal 'constitutional common law,' informed largely by the twin aims of redressing constitutional violations on an individual level and ensuring that government officials obey constitutional norms." (footnote omitted)).

32 See Fallon \& Meltzer, supra note 16, at 1778 (noting that remedies for constitutional violations have come through legal and equitable forms such as "damages, restitution, injunctions, mandamus, ejectment, declaratory judgments, exclusion of evidence, remand for retrial or reconsideration untainted by constitutional error, and writs of habeas corpus"). 
treatment, for example, to injunctions, declaratory judgments, or writs of mandamus or prohibition when I am discussing remedies that have the effect of causing a government actor to desist unconstitutional conduct or refrain from an imminent violation of rights. Rather, I group all such forms of relief together under more general headings such as "Nullification of Unconstitutional Laws by Subjects of Government Enforcement Actions" and "Remedies Ameliorating Other Ongoing or Imminent Constitutional Violations."

\section{A FUNCTIONAL ClASSIFICATION OF CONSTITUTIONAL REMEDIES}

\section{A. A Need to Escape History}

Although the historical practice of classifying remedies as either "legal" or "equitable" remains the norm, the historical practice often confuses far more than it clarifies. Professor Douglas Laycock, a leading expert on the law of remedies, explains why this is so:

The line between law and equity is largely the result of a bureaucratic fight for turf; each set of courts [i.e., the separate law and equity courts that existed both in England and throughout the United States prior to last century's merger of law and equity] took as much jurisdiction as it could get. Consequently, the line is jagged and not especially functional; it can only be memorized. Damages are the most important legal remedy; in general, compensatory and punitive remedies are legal. Injunctions and specific performance decrees are the most important equitable remedies; some of the specialized coercive remedies, such as mandamus, prohibition, and habeas corpus, are legal. Declaratory judgments were created by statute after the merger, so they are not classified either way; most of the older, more specialized declaratory remedies are equitable. Restitution was developed independently in both sets of courts; some restitutionary remedies are legal, some equitable, and some both. ${ }^{34}$

In an earlier edition of his casebook, ${ }^{35}$ Laycock illustrated how use of the historical law/equity distinction can cause practical problems by contrasting the Supreme Court's 1993 decision in Mertens v. Hewitt Associates ${ }^{36}$ with its 2002 decision in

\footnotetext{
33 See infra Parts II.B.2.a-b.

34 LAYCOCK, supra note 2, at 6.

35 DOUGLAS LAYCOCK, MODERN AMERICAN REMEDIES (3d ed. 2002).

36508 U.S. 248 (1993).
} 
Great-West Life \& Annuity Co. v. Knudson. ${ }^{37}$ In Mertens, the Court by a 5-4 vote construed Congress's use of the phrase "equitable relief" in Section 502(a)(3) of the Employee Retirement Income Security Act of 1974 (ERISA) ${ }^{38}$ to encompass only remedies "that are typically available in equity," and not all remedies actually available in an equity court prior to the merger. ${ }^{39}$ But in Great-West, Laycock persuasively demonstrates, the Court (again, in a 5-4 split) effectively adopted the latter, more technical meaning of the very same statutory provision. ${ }^{40}$

Laycock uses this discussion of Mertens and Great-West to illustrate two broader themes that pervade his work. First, it often would be far more useful if Congress, judges, and commentators were to use functional, rather than historical, law/equity language when classifying constitutional remedies. ${ }^{41}$ Second, functionally speaking, " $\left.t\right]$ he most fundamental remedial choice is between substitutionary and specific remedies. ${ }^{\$ 42}$ I agree. Therefore, in order to lay the groundwork for the analysis and arguments that follow, I start by classifying recognized constitutional remedies in functional terms, as either substitutionary or specific. Hopefully, the utility of this functional classification scheme will become apparent as readers proceed through the rest of the paper.

37534 U.S. 204 (2002).

${ }^{38}$ Pub. L. No. 93-406, 88 Stat. 829 (codified as amended at 29 U.S.C. $\S 1001$ et seq. (2006)). Section 502(a)(3) of ERISA may be found at 29 U.S.C. $\S 1132(a)(3)(2006)$.

${ }^{39}$ Mertens, 508 U.S. at 256 (noting that "[a]s memories of the divided bench, and familiarity with its technical refinements, recede further into the past," it is less likely that Congress intended that the phrase "equitable remedies" be construed with historical precision).

${ }^{40}$ See LAYCOCK, supra note 2, at 568-69. I emphasize that this is Laycock's characterization of Great-West because the majority's opinion acknowledges no departure from Mertens. Indeed, Justice Scalia authored the majority opinions in both Mertens and GreatWest , and sought throughout the latter to emphasize its consistency with the former. See GreatWest, 534 U.S. at 209-20.

${ }^{41}$ See LAYCOCK, supra note 2, at 3.

${ }^{42} I d$. at 5 (quoting LAYCOCK, supra note 2, at 12-13). Of course, remedies may also be classified as either prospective or retrospective, depending on how they operate. Edelman $v$. Jordan, 415 U.S. 651 (1974), employed this distinction to differentiate between those injunctions requiring the expenditure of state funds that may lawfully be entered against state officials under the doctrine recognized in Ex parte Young, 209 U.S. 123 (1908), and those that are effectively suits against the State and therefore barred by the Eleventh Amendment. Edelman concluded that the Eleventh Amendment permits prospective injunctions of this sort but bars injunctions that operate retrospectively. See 415 U.S. at $664-70$. The distinction between prospective and retrospective remedies has proved to be quite difficult to draw and rationalize in practice. See generally LAYCOCK, supra note 2, at 475 ("The line between prospective and retrospective remedies is neither self-evident nor self-executing."); Amar, supra note 14, at 1480 (describing the Supreme Court's cases in the area as "incoherent"); Vicki C. Jackson, The Supreme Court, the Eleventh Amendment, and State Sovereign Immunity, 98 Y ALE L.J. 1, 88 $\& n .353$ (1988) (noting the "numerous grounds" on which the distinction has been criticized); Carlos Manuel Vázquez, Night and Day: Coeur d'Alene, Breard, and the Unraveling of the Prospective-Retrospective Distinction in Eleventh Amendment Doctrine, 87 GEO. L.J. 1, 3 (1998) (noting the distinction's "inadequacies"). 


\section{B. Substitutionary and Specific Constitutional Remedies}

There is an initial need to define terms. Laycock describes the difference between substitutionary and specific remedies as follows:

With substitutionary remedies, plaintiff suffers harm and receives a sum of money. Specific remedies seek to avoid this exchange. They aspire to prevent harm, or undo it, rather than let it happen and compensate for it. They seek to prevent harm to plaintiff, repair the harm in kind, or restore the specific thing that plaintiff lost. Substitutionary remedies include compensatory damages, attorneys' fees, restitution of the money value of defendant's gain, and punitive damages. Specific remedies include injunctions, specific performance of contracts, restitution of specific property, and restitution of a specific sum of money. ${ }^{43}$

Laycock's descriptive definitions of substitutionary and specific remedies are typical, ${ }^{44}$ and they are helpful as far as they go. But typical definitions of substitutionary and specific remedies such as these are incomplete and inadequate for wholesale application in the unique context of constitutional remedies. For example, typical definitions may be taken to suggest that money is the only substitutionary remedy ${ }^{45}$ Yet this is inaccurate. Non-monetary substitutionary injunctions are sometimes available, ${ }^{46}$ and there are other substitutionary constitutional remedies that are non-monetary. ${ }^{47}$ In addition, substitutionary remedies are not inevitably compensatory, as typical definitions

43 LAYCOCK, supra note 1, at 12-13.

44 See Colleen P. Murphy, Money as a "Specific" Remedy, 58 AlA. L. REV. 119, 122-23 \& nn.14-15(2006) (collecting common definitions); see also id. at 122-23 ("The difference between specific and substitutionary remedies can be further understood in terms of the plaintiff's rightful position-the position the plaintiff would hold if the defendant did not violate the plaintiff's legal rights. Specific relief achieves the plaintiff's rightful position exactly; substitutionary relief achieves only a rough approximation.").

45 See LAYCOCK, supra note 2, at 6; see also Murphy, supra note 44, at 124 \& n.22 (citing JAMES M. FISCHER, UNDERSTANDING REMEDIES $§ 2$ [b], at 4 (1999)) (noting that Fischer gives only damages as an example of a substitutionary remedy); id. (citing ROBERT N. LEAVELL ET AL., EQUITABLE REMEDIES, RESTITUTION AND DAMAGES 1 (7th ed. 2005)) (stating that substitutionary relief substitutes money for specific relief).

46 See E. Allan FARNSWORTH, FARNSWORTH ON CONTRACTS $\S 12.4$, at 850 n.2 (2d ed. 1990) ("[S]ubstitutional relief could, in theory, be in kind rather than in money."); Murphy, supra note 44 , at $124 \&$ n. 25 (providing as an example a nonmonetary substitutionary injunction ordering that a person unlawfully denied a promotion be placed in a different position because the position she sought had since been filled); see also infra Part II.B.1.d (discussing structural reform injunctions rooted in constitutional violations that exceed the scope of the violation that justified judicial intervention).

47 See infra Parts II.B.1.b-c (discussing the exclusion of evidence at trial and reversal of judgments tainted by constitutional error). 
can be read to imply; they may be justified entirely by public policy goals unrelated to harm suffered by the right-holder, as is the case with the Fourth Amendment's exclusionary rule. ${ }^{48}$

For purposes of understanding the classification scheme that follows, an instrumental definition that focuses on the difference between substitutionary and specific remedies will be more useful. Borrowing from Professor Colleen Murphy, I adopt the following as my working definition: "[S]pecific remedies provide the original thing or condition to which the [claimant] was entitled, while substitutionary remedies provide something else. ${ }^{, 49}$ Under this definition, specific constitutional remedies permit a rightholder to halt an ongoing, or avoid an imminent, unconstitutional deprivation of life, liberty, or property; in other words, they provide or restore to the right-holder the very freedom, interest, or thing that the Constitution promises. Substitutionary constitutional remedies, by contrast, provide "something else" to victims of constitutional violationsusually (although not always ${ }^{50}$ ) because the violation is wholly realized by the time it is raised in court and therefore cannot be headed off, halted, or undone. ${ }^{51}$

\section{Substitutionary Constitutional Remedies}

\section{a. Damages}

Even though a judgment ordering the defendant to pay money to the plaintiff is not the only substitutionary constitutional remedy, it is the prototypical example of substitutionary relief. Victims of constitutional violations are sometimes entitled to seek damage awards from federal actors under the Bivens doctrine $\mathrm{s}^{52}$ and more frequently

48 See United States v. Calandra, 414 U.S. 338, 347-48 (1974) (rejecting the theory that Fourth Amendment exclusion is a "personal constitutional right of the party aggrieved" and emphasizing that the exclusionary rule's purpose is to deter police misconduct "to safeguard Fourth Amendment rights generally").

${ }^{49}$ Murphy, supra note 44, at 126; see also FISCHER, supra note 45, at $\S 2.2$ ("A substitutional remedy is something other than a specific remedy.").

so See infra note 139 and accompanying text.

st See Murphy, supra note 44, at 137-38 \& n.11 (explaining that remedies for harms that have accrued prior to the date of a judgment are usually substitutionary).

52 See Bivens v. Six Unknown Named Agents, 403 U.S. 388 (1971) (authorizing plaintiffs to vindicate certain constitutionally protected rights by means of a damages action against federal officials sued in their individual capacities). A Bivens claim lies directly under the constitutional provision in question and 28 U.S.C. $\S 1331$ (2006), which confers on the federal courts jurisdiction over claims "arising under the Constitution." See, e.g., Carlson v. Green, 446 U.S. $14,16(1980)$. Since 1980 , the Supreme Court has repeatedly refused to permit the assertion of Bivens claims in any context other than the three that were authorized between 1971 and 1980: Fourth Amendment violations, see Bivens, 403 U.S. at 389, gender discrimination, see Davis v. Passman, 442 U.S. 228, 248-49 (1979); and deliberate indifference to medical needs in violation of the Eighth Amendment, see Carlson, 446 U.S. at 16-18 (1980). See Minneci v. Pollard, 132 S. Ct. 617, 622-23 (2012) (detailing five cases from 1983 to 2012 in which the 
entitled to do so from state actors under 42 U.S.C. $\S 1983 .{ }^{53}$ Such suits, which may initially be filed in either federal or state court, usually name as defendants the individual government actor who was the agent through whom the federal, state, or local government visited constitutional harm on the plaintiff. ${ }^{54}$ Such "individual capacity" actions are pervasive because sovereign immunity shields the federal government from damages claims under Bivens ${ }^{55}$ and because states and their subdivisions are not "persons" subject to suit within the meaning of Section $1983 .{ }^{56}$ In fact, the only type of government entity subject to a suit for money damages for an alleged constitutional violation is a unit of local government such as a municipality. ${ }^{57} \mathrm{But}$ local government units are not liable for the conduct of their employees under a theory of respondeat superior. ${ }^{58}$ Rather, they are subject to Section 1983 liability only when the plaintiff's injuries have been caused by an unlawful "policy or custom" 59 -a concept that has been narrowly defined and is therefore quite difficult to prove. ${ }^{60}$ Thus, as already noted, most constitutional claims for money name individual defendants. ${ }^{61}$

Court refused to recognize a Bivens claim and rejecting the petitioner's Eighth Amendment claim). It has cautioned that judicial implication of a damages remedy for constitutional violations should not proceed if there exist alternative processes for protecting the constitutionally recognized interest, including state tort law. See id. at 621 (applying analysis prescribed in Wilkie v. Robbins, 551 U.S. 537, 550 (2007)). And even where such alternative processes do not exist, courts should heed any special factors that counsel hesitation on the part of a common law tribunal to authorize a new kind of federal litigation. See id. For an excellent overview of recent developments in Bivens jurisprudence, and for an intriguing proposal to set this body of jurisprudence on a straighter course, see James E. Pfander \& David Baltmanis, Rethinking Bivens: Legitimacy and Constitutional Adjudication, 98 GEO. L.J. 117 (2009).

53 In relevant part, 42 U.S.C. $\S 1983$ (2006) states:

Every person who, under color of any statute, ordinance, regulation, custom, or usage, of any State or Territory or the District of Columbia, subjects, or causes to be subjected, any citizen of the United States or other person within the jurisdiction thereof to the deprivation of any rights, privileges, or immunities secured by the Constitution and laws, shall be liable to the party injured in an action at law, suit in equity, or other proper proceeding for redress ....

${ }^{54}$ See, e.g., Smith v. Wade, 461 U.S. 30 (1983) (considering a suit brought under 42 U.S.C. $\S 1983$ against a prison correctional officer in federal court).

${ }^{55}$ See FDIC v. Meyer, 510 U.S. 471, 485 (1994).

${ }^{56}$ See Will v. Michigan Dep't of State Police, 491 U.S. 58, 64 (1989).

57 See Monell v. Dep't of Soc. Servs., 436 U.S. 658, 690, 700 (1978) (overruling Monroe v. Pape, 365 U.S. 167, 187-91 (1961), and holding that municipalities are "persons" subject to suit under Section 1983).

58 See id. at 691.

59 See id. at 694-95.

${ }^{60}$ See, e.g., Richard H. Fallon, Jr., The "Conservative" Paths of the Rehnquist Court's Federalism Decisions, 69 U. CHI. L. REV. 429, 463-64 \& n.226 (2002); John C. Jeffries, Jr., Essay, The Right-Remedy Gap in Constitutional Law, 109 YALE L.J. 87, 93 (1999).

${ }^{61}$ Although constitutionally based money judgments tend to run nominally against individual defendants, the government agency that employs the individual will almost invariably 
Civil rights plaintiffs are entitled to seek compensatory and punitive damages under Bivens $^{62}$ and Section $1983,{ }^{63}$ except that punitive damages are unavailable in a claim against a municipality. ${ }^{64}$ Civil rights plaintiffs may also recover attorney's fees for a successful claim under Section 1983, ${ }^{65}$ but not for a successful claim under Bivens. ${ }^{66}$

\section{b. The Exclusion of Evidence Obtained as a Result of a Wholly Realized Constitutional Violation}

The exclusion of evidence at trial in either federal or state court can either constitute a remedy for a wholly realized constitutional wrong or work to head off an imminent constitutional violation. Professor Arnold Loewy provides a succinct explanation of why this is so:

The exclusion of police-obtained evidence at a criminal trial can be justified by one of two theories. Under one theory, evidence is excluded because the police have unconstitutionally obtained the evidence and exclusion is thought desirable to deter such police behavior in the future by precluding a substantial benefit from such misconduct. Under the other theory, the evidence is excluded because the Constitution guarantees the defendant a procedural right to exclude the evidence. The former theory focuses on the constitutional impropriety of obtaining the evidence, while the latter theory's focus is on the constitutional impropriety of using that evidence at trial. ${ }^{67}$

supply the defendant with a defense, and will commonly foot the bill for an adverse judgment. State agencies and municipalities commonly take out insurance policies that oblige the insurer to defend and indemnify state and municipal employees against such claims. See John M. Greabe, Iqbal, al-Kidd, and Pleading Past Qualified Immunity: What the Cases Mean and How They Demonstrate a Need to Eliminate the Immunity Doctrines from Constitutional Tort Law, 20 WM. \& MARY BILL RTS. J. 1, 31 n.187 (2011). The federal government, in contrast, typically supplies a federal government attorney to defend individual employees sued under Bivens. See id. (citing 28 C.F.R. $\S 50.15$ (a) (2010)). But there are opt-out provisions that can lead to the government supplying private counsel for Bivens defendants if a conflict arises between the defendant's interests and the interests of the United States. See id. (citing 28 C.F.R. $\S \S 50.15(\mathrm{a})(8), 50.15(\mathrm{a})(11)(\mathrm{ii}-\mathrm{iii}), 50.16(\mathrm{a})(2010))$.

${ }_{62}$ See Carlson v. Green, 446 U.S. 14, 21-22 (1980).

${ }^{63}$ See Smith v. Wade, 461 U.S. 30, 56 (1983).

${ }^{64} \mathrm{See}$ City of Newport v. Fact Concerts, Inc., 453 U.S. 247, 271 (1981).

${ }^{65}$ See 42 U.S.C. § 1988(b) (2006).

${ }_{66}^{6}$ See, e.g., Kreines v. United States, 33 F.3d 1105 (9th Cir. 1994).

${ }^{67}$ Arnold H. Loewy, Police-Obtained Evidence and the Constitution: Distinguishing Unconstitutionally Obtained Evidence from Unconstitutionally Used Evidence, 87 MICH. L. REV. 907, 907 (1989) (footnote omitted). 
Put in remedial terms, the act of exclusion under the former theory constitutes substitutionary relief for a wholly realized constitutional violation committed at the time the evidence was obtained.$^{68}$ But the act of exclusion under the latter theory permits the moving party to receive that to which she is specifically entitled under the Constitution: avoidance of the procedural constitutional violation that would occur upon admission of the evidence. ${ }^{69}$

The exclusion of evidence at trial has long been recognized in connection with violations of the Fourth, ${ }^{70}$ Fifth, ${ }^{71}$ and Sixth Amendments, ${ }^{72}$ and the Due Process Clauses of the Fifth and Fourteenth Amendments. ${ }^{73}$ For example, the exclusion of evidence obtained by federal agents in violation of the Fourth Amendment was first required nearly a century ago in Weeks $v$. United States ${ }^{74}$ and was extended by the Warren Court to evidence obtained in violation of the Fourth Amendment by state agents in Mapp $v$. Ohio. ${ }^{75}$ The exclusion of evidence obtained in violation of the constitutional rule announced in Miranda v. Arizona ${ }^{76}$ fashioned to protect Fifth- and Sixth-Amendment rights, ${ }^{77}$ was authorized in Miranda itself. ${ }^{78}$ The exclusion of evidence otherwise obtained in violation of the Fifth and Sixth Amendments also is well established, ${ }^{79}$ as

68 Of course, the erroneous admission of evidence obtained as a consequence of the earlier constitutional violation could establish or contribute to a second constitutional violation-a deprivation of the right to a fair trial. See Delaware v. Van Arsdall, 475 U.S. 673, 681 (1986) ("[T]he Constitution entitles a criminal defendant to a fair trial, not a perfect one."). Such a wholly realized second constitutional violation can also only be remedied post hoc through the provision of a substitutionary remedy - reversal of any judgment of conviction that might follow the erroneous admission of evidence — on direct or collateral review. See infra Part II.B.1.c.

${ }^{69}$ It seems odd to classify such an act of exclusion as a "remedy" because no constitutional violation has occurred and the situation is not analogous to a claim for pre-enforcement review of an unconstitutional statute that a government official has declared an intention to enforce. See infra Parts II.B.1.a-b.

70 U.S. CONST. amend. IV ("The right of the people to be secure in their persons, houses, papers, and effects, against unreasonable searches and seizures, shall not be violated . ...").

71 U.S. CONST. amend. V ("No person ... shall be compelled in any criminal case to be a witness against himself ....").

72 U.S.CONST. amend. VI ("In all criminal prosecutions, the accused shall enjoy the right... to be confronted with the witnesses against him ... and to have the Assistance of Counsel for his defence.").

73 U.S. CONST. amend. V, $\S 1$ (guaranteeing an accused "due process of law"); U.S. CONST. amend. XIV, § 1 (same).

74 See 232 U.S. 383 (1914).

75 See 367 U.S. 643 (1961).

76 See 384 U.S. 436 (1966). The Supreme Court made clear that Miranda is a constitutional rule in Dickerson v. United States, 530 U.S. 428, 444 (2000).

77 See Miranda, 384 U.S. at 442-44.

78 See id. at $476-77$.

79 See, e.g., Maine v. Moulton, 474 U.S. 159, 170-74 (1985) (excluding evidence obtained through interrogation by state officials in violation of the right to assistance of counsel); Mincey v. Arizona, 437 U.S. 385, 398-99(1978) (excluding incriminating statements unlawfully coerced 
is the exclusion under the Due Process Clauses of unreliable eyewitness evidence obtained through police misconduct. ${ }^{80}$

A violation of the Fourth Amendment is wholly realized at the time the unlawful search or seizure is conducted ${ }^{81}$ So is a violation of the Sixth Amendment right to counsel under the rule recognized in Massiah v. United States. ${ }^{82}$ Some coerced confessions-for example, those whose brutality stands as an independent constitutional violation, irrespective of whether evidence obtained as a consequence of the episode is subsequently admitted at trial-likely fall into this same category; others likely do not. ${ }^{83}$ Thus, judicial orders excluding evidence obtained in violation of either the Fourth Amendment or the Sixth Amendment rule protected by Massiah, or excluding confessions obtained in consequence of interrogations that violate the Constitution, provide substitutionary relief.

By contrast, if only the admission of evidence obtained in violation of the Miranda rule constitutes a constitutional violation, ${ }^{84}$ a judicial order excluding such evidence would avoid the violation. ${ }^{85}$ This is clearly the case with, for example, a ruling, order, or instruction protecting a criminal defendant's Sixth Amendment confrontation rights under the rule established in Crawford $v$. Washington. ${ }^{86}$ The same is true with a ruling, order, or instruction protecting a criminal defendant's Fifth Amendment privilege against self-incrimination under the rules established in Griffin v. California. ${ }^{87}$ Note

by state officials); United States v. Wade, 388 U.S. 218, 239-41 (1967) (excluding identification secured at post-indictment lineup at which counsel was not present); Massiah v. United States, 377 U.S. 201, 206 (1964) (excluding evidence obtained through interrogation by federal officials in violation of the right to assistance of counsel); Bram v. United States, 168 U.S. 532, $542-43$ (1897) (excluding incriminating statements unlawfully coerced by federal officials).

${ }^{80}$ See, e.g., Perry v. New Hampshire, 132 S. Ct. 716, 723-25 (2012) (summarizing Supreme Court cases involving unreliable eyewitness testimony secured through police misconduct).

${ }^{81}$ See Loewy, supra note 67, at 908-16.

82377 U.S. at 206. The Supreme Court held that a Massiah violation is completed at the time of the unlawful interrogation in Kansas v. Ventris, 129 S. Ct. 1841, 1846 (2009).

${ }^{83}$ See Loewy, supra note 67, at 933-37.

84 The Supreme Court has not decided whether a constitutional Miranda violation is complete at the time of the unlawful police conduct, or whether it becomes complete only with the admission at trial of evidence secured in violation of the required warnings. A plurality of the Court has taken the latter view, but the proposition has yet to garner majority support. See Chavez v. Martinez, 538 U.S. 760, 767, 772-73 (2003) (plurality opinion).

${ }^{85}$ See supra note 68 and accompanying text.

${ }^{86}$ See 541 U.S. 36, 68-69 (2004) (finding out-of-court, testimonial witness statements inadmissible unless the witness is unavailable and the accused had a prior opportunity to crossexamine the witness). Imagine here a judicial order barring the prosecution from using such a statement or instructing the jury to ignore any evidence of such a statement that might have been presented to it.

${ }^{87}$ See 380 U.S. 609, 615 (1965) (barring a prosecutor from asking the jury to draw an adverse inference from a criminal defendant's refusal to testify and barring a judge from instructing the jury that an adverse inference may be drawn from such silence). Imagine here 
also that the issue does not arise only in the criminal law context. To take a final example, a ruling, order, or instruction that works to protect the defendant from a jury award that would work a denial of due process under the rule announced in Philip Morris USA $v$. Williams ${ }^{88}$ also avoids a procedural constitutional violation. ${ }^{89}$

The foregoing examples serve only to illustrate; they do not provide an exhaustive account of the range of possible scenarios in which requests for the exclusion of evidence or for the preclusion of argument or instruction raise issues of constitutional dimension.

\section{c. Reversal of a Judgment Infected by Constitutional Error}

As discussed in the preceding subsection, litigants often ask federal and state trial judges to provide substitutionary constitutional remedies and to issue rulings that enforce procedural guarantees that are based in the Constitution. ${ }^{90}$ But what if a trial judge errs by admitting evidence that she should not have admitted and then subsequently enters a judgment that is adverse to the right-holder? Or what if a prosecutor or a criminal defense attorney acts to deprive a right-holder of procedural guarantees based in the Constitution, ${ }^{91}$ and (again) a judgment subsequently enters that is adverse to the rightholder? Or what if the trial itself is marred by a constitutional error such as, to take only one of many possible examples, a jury instruction that effectively relieves the prosecution of its burden of proving each element of the crime beyond a reasonable doubt? ${ }^{92}$

Whenever one of these things happens, a "constitutional" wrong has been committed. ${ }^{93}$ In such circumstances, there is a wide array of procedural mechanisms that

a judicial order instructing the jury to disregard a comment by the prosecutor that violated the rule established in Griffin.

88549 U.S. 346 (2007).

${ }^{89}$ See id. at 353-55 (finding that a damage award punishing a defendant for injuring nonparties constitutes a taking of property without due process). Imagine here an instruction informing a jury presented with evidence that defendant's conduct harmed non-parties that it cannot punish the defendant for harm done to non-parties. $C f$. Reynoldsville Casket Co. v. Hyde, 514 U.S. 749 (1995) (holding that petitioner was not subject to a state law tolling provision that was struck down on constitutional grounds while a lawsuit against petitioner was pending).

${ }^{90}$ See supra Part II.B.1.b.

91 See, e.g., Wiggins v. Smith, 539 U.S. 510, 523-34 (2003) (finding that failure of defense counsel in a capital case to investigate the defendant's life history for mitigating evidence beyond that discovered by government agencies constituted ineffective assistance of counsel in violation of the Sixth Amendment); Brady v. Maryland, 373 U.S. 83, 87 (1963) (finding that a prosecutor's withholding of evidence material to the guilt or innocence of the accused is a violation of due process).

${ }_{92}$ See Sandstrom v. Montana, 442 U.S. 510, 520-24 (1979) (stating that jury instruction may not use evidentiary presumptions that relieve the government of its burden under Winship); In re Winship, 397 U.S. 358, 364 (1970) (holding that the government must prove each element of a criminal offense beyond a reasonable doubt).

93 The erroneous admission of evidence previously obtained in violation of the Fourth Amendment does not itself comprise a second constitutional violation. See, e.g., United States 
the right-holder may use to request reversal of the tainted judgment if she has preserved her claim for review..$^{94}$ The right-holder may, for example, seek relief from the trial court itself. ${ }^{95}$ Or the right-holder may directly appeal the judgment and request reversal from an appellate court. ${ }^{96}$ And in the case of a criminal judgment, the rightholder may also seek relief by means of a collateral attack on the tainted judgment. ${ }^{97}$ Any relief obtained pursuant to such a procedural mechanism is substitutionary because the constitutional violation being challenged is concluded at the time of the post hoc challenge and because trials are not fungible. ${ }^{98}$ Any new trial (or decision not to initiate a second trial) following an order reversing the judgment thus functions as a substitute for the wholly realized constitutional wrong.

\section{d. Provisions of Structural Reform Injunctions That Are Unnecessary to Prevent or Undo a Constitutional Violation}

In the decades since the Supreme Court's merits decision and remedial ruling in Brown v. Board of Education, ${ }^{99}$ the Court has upheld a number of lower court structural reform injunctions that have been based on findings that the conditions prevalent in state and local institutions such as school districts, prisons, mental hospitals, and

v. Leon, 468 U.S. 897, 906 (1984) (noting that the Constitution does not require the exclusion of evidence obtained in violation of the Fourth Amendment). But the Supreme Court analyzes such an error as "constitutional" for purposes of harmless error review. See Arizona v. Fulminante, 499 U.S. 279, 306-07 (1991) (citing Chambers v. Maroney, 399 U.S. 42, 52-53 (1970)) (affirming the use of a constitutional harmless-error analysis).

${ }^{94}$ If she has not preserved her claim, she may still argue that the error was plain and therefore susceptible to being noticed notwithstanding her procedural default. See FED. R. CIV.P. 51(d)(2); FED. R. CRIM. P. 52(b). See generally United States v. Olano, 507 U.S. 725 (1993) (elaborating on the unforgiving "plain error" standard).

95 To avoid unnecessary prolixity, I confine my exemplary citations in this footnote and the next two to federal mechanisms available to seek reversal of a judgment infected by constitutional error. See, e.g., FED. R. CIV. P. 59 (new trial or alteration or amendment of a judgment); FED. R. CIV. P. 60 (relief from judgment or order); FED. R. CRIM. P. 29 (acquittal); FED. R. CRIM. P. 33 (new trial). Obviously, parallel procedural mechanisms are available in each state.

${ }^{96}$ See, e.g., 28 U.S.C. $\$ 1291$ (2006) (authorizing appeals from final decisions of federal district courts); 28 U.S.C. $\$ 1292$ (2006) (authorizing appeals from some interlocutory decisions of the federal district courts). Federal appeals are governed by the Federal Rules of Appellate Procedure, FED. R. APP. P. 1(a)(1), and, in the event further review is sought in the U.S. Supreme Court, by the Rules of the Supreme Court of the United States, SUP. CT. R. 48(2).

97 See 28 U.S.C. $\$ 2254$ (2006) (authorizing collateral attack on state judgments); 28 U.S.C. $\S 2255$ (2006) (authorizing collateral attack on federal judgments).

${ }^{98}$ Cf. infra Part II.B.2.e (describing how a restitutionary tax refund, owed as a matter of due process, constitutes specific relief ameliorating the ongoing wrongful denial of a postdeprivation remedy for the imposition of an unconstitutional tax).

99 See Brown v. Board of Education (Brown II) 349 U.S. 294 (1955); Brown v. Board of Education (Brown I), 347 U.S. 483 (1954). 
housing authorities have violated the individual constitutional rights of the plaintiffs and, in the case of class actions, of the plaintiff class. ${ }^{100}$ These injunctions have required comprehensive changes to the defendant institutions. ${ }^{101}$ Many provisions of the structural decrees that the Court has upheld, at least in the decades immediately following Brown, required relief that went well beyond preventing or undoing the underlying constitutional violation that justified judicial intervention. ${ }^{102}$ Whether such provisions remain lawful today is, at best, an open question. In recent years, the Court has repeatedly emphasized that structural reform injunctions should be restorative in that they should seek only to place victims in the position they rightfully would have held but for the identified violation of the Constitution. ${ }^{103}$ In any event, to the extent that injunctions may still lawfully contain provisions that outrun the scope of the underlying constitutional violation, such provisions are "substitutionary" in the sense that they provide the plaintiffs with something other than that to which the Constitution specifically entitles them. ${ }^{104}$

${ }^{100}$ The paradigmatic cases from the school desegregation context are Swann $y$. CharlotteMecklenberg Bd. of Educ., 402 U.S. 1, 28-31 (1971), and Green v. Cnty. Sch. Bd., 391 U.S. 430,437-38 (1968). Examples of cases from the other contexts mentioned may be found in Charles F. Sabel \& William H. Simon, Destabilization Rights: How Public Law Litigation Succeeds, 117 HARV. L. REV. 1015, 1029-52 (2004).

101 See Sabel \& Simon, supra note 100, at 1022-52. In the areas of police abuse, however, the changes have come mostly from congressional mandates and public disapprobation. See id. at 1043-47; cf. LAYCOCK, supra note 2, at 329 ("[T] $]$ he federal courts supervised the reform... in nearly every state.").

102 See, e.g., LAYCOCK, supra note 2, at 311 (observing that Swann contained provisions that far exceeded the underlying constitutional violation); $i d$. at 330 (discussing a provision of the injunction upheld in Hutto v. Finney, 437 U.S. 678 (1978), which prohibited Arkansas prisons from placing inmates into punitive isolation for more than 30 days); Chayes, supra note 10, at 1302; see also Jeffries \& Rutherglen, supra note 10, at 1387; Paul J. Mishkin, Federal Courts as State Reformers, 35 WASH. \& LEE. L. REV. 949, 955-58 (1978).

103 See LAYCOCK, supra note 2, at 310-36 (discussing how the law evolved in this direction in cases such as Milliken v. Bradley, 418 U.S. 717 (1974) (striking down an injunction that ordered a multi-district desegregation remedy when only one school district had been adjudged a constitutional violator); Missouri v. Jenkins, 515 U.S. 70 (1995) (striking down injunction that contained provisions that went far beyond restoring victims of unlawful segregation to the position they would have occupied absent such conduct); and Lewis v. Casey, 518 U.S. 343 (1996) (similar, with respect to an injunction that ordered significant upgrades to prison law libraries in Arizona)). Even in the Court's recent decision upholding an injunction requiring California to reduce its prison population, the rhetoric of necessity and narrow tailoring permeates the majority's analysis. See, e.g., Brown v. Plata, 131 S. Ct. 1910, 1929 (2011) (noting that "courts may enter orders placing limits on a prison's population" when doing so is "necessary to ensure compliance with a constitutional mandate"); $i d$. at 1940 (noting that the Court has "rejected remedial orders that unnecessarily reach out to improve prison conditions other than those that violate the Constitution"); id. at 1944 ("Of course, courts must not confuse professional standards with constitutional requirements.").

${ }^{104}$ See supra note 49 and accompanying text; see also Murphy, supra note 44, at 124-26 $\& \mathrm{n} .26$ (characterizing as substitutionary a structural reform injunction ordering the building 
2. Specific Constitutional Remedies

\author{
a. Nullification of Unconstitutional Laws by Subjects of Government \\ Enforcement Actions
}

There is no more basic and essential remedy for the violation of a constitutional right than a holding in favor of the subject of a government enforcement action that the federal or state law by which the government proceeds is unconstitutional, either on its face or as applied to the subject. ${ }^{105}$ In the paradigmatic case, the subject is charged with a crime or subjected to a coercive civil enforcement action and asserts defensively the unconstitutionality of the law (again, facially or as applied) by which the government proceeds. ${ }^{106}$ Famous examples of such cases include United States v. Lopez ${ }^{107}$ and Brandenburg v. Ohio. ${ }^{108}$ Alternatively, the subject of an imminent enforcement action sometimes may, without facing a sovereign immunity bar (in the case of a claim against a federal official) ${ }^{109}$ or an Eleventh Amendment bar (in the case of a claim against a

of recreational facilities at a prison as a remedy for past unlawful overcrowding in violation of the Eighth Amendment).

105 See FALlON ET AL., HART AND WECHSLER, supra note 10, at 718; Jeffries \& Rutherglen, supra note 10 , at $1391-92$.

${ }_{106}$ See Jeffries \& Rutherglen, supra note 10, at 1391-92.

107514 U.S. 549 (1995) (overturning a conviction under the federal Gun-Free School Zones Act because the Commerce Clause did not authorize Congress to pass the Act).

108 395 U.S. 444 (1969) (overturning a conviction under Ohio's Criminal Syndicalism Statute because the Statute violated the First Amendment on its face).

109 The second sentence of Section 702 of the Administrative Procedure Act, 5 U.S.C. $\$ 702$ (2006) (APA), has been widely read to waive sovereign immunity with respect to official capacity claims against federal officials. Section 702 provides:

A person suffering legal wrong because of agency action, or adversely affected or aggrieved by agency action within the meaning of a relevant statute, is entitled to judicial review thereof. An action in a court of the United States seeking relief other than money damages and stating a claim that an agency or an officer or employee thereof acted or failed to act in an official capacity or under color of legal authority shall not be dismissed nor relief therein be denied on the ground that it is against the United States or that the United States is an indispensable party.

Id. That said, it is not entirely settled whether Section 702 of the APA waives sovereign immunity broadly, or only with respect to actions against federal officials that are brought under other provisions of the APA. But the recent and consistent trend in the federal courts of appeals has been to read the second sentence of Section 702 as a broad waiver of immunity and not one limited solely to actions brought under the APA. See, e.g., Treasurer of N.J. v. U.S. Dep't of the Treasury, 684 F.3d 382 (3d Cir. 2012) (holding that APA waivers are not limited to actions brought under the Act); Michigan v. U.S. Army Corps of Eng'rs, 667 F.3d 765, 775 (7th Cir. 2011) (subjecting federal officials to state common law through the APA), cert. denied, 132 S. Ct. 1635 (2012); Delano Farms Co. v. Cal. Table Grape Comm'n, 655 F.3d 1337, 1344 (Fed. Cir. 2011) (allowing sovereign immunity to apply in patent law claims); Veterans for Common Sense v. Shinseki, 644 F.3d 845, 866 (9th Cir. 2011)(finding the Veterans Administration unable 
state official) ${ }^{110}$ seek pre-enforcement review by means of a prospective federal action against the government official(s) poised to enforce the allegedly unconstitutional law. Such actions may proceed under the Declaratory Judgment Act $^{111}$ so long as they are otherwise justiciable and proper. ${ }^{112}$ When asserting one's rights in this way, either defensively or offensively, the subject of the enforcement action seeks the specific remedy of freedom from the unconstitutional constraint or coercion that would be worked by the challenged statute if it were enforced against the right-holder. ${ }^{113}$

\section{b. Remedies Ameliorating Other Ongoing or Imminent Constitutional Violations}

Victims of unconstitutional conduct may also seek prospective relief against government officials acting in their official capacities to ameliorate other ongoing or imminent violations of individual constitutional rights ${ }^{114}$ (i.e., ongoing or imminent violations

to invoke sovereign immunity against a constitutional claim), aff' $d$ in part, rev'd in part, 678 F.3d 1013 (9th Cir. 2012); Puerto Rico v. United States, 490 F.3d 50, 57-58 (1 st Cir. 2007) (applying waiver to any official action), cert. denied, 552 U.S. 1295 (2008).

${ }_{110}$ See Ex parte Young, 209 U.S. 123 (1908) (holding that the Eleventh Amendment does not bar injunctive relief against state officials who act, or will act imminently, in violation of the Constitution, and authorizing shareholders of a railroad subject to an imminent enforcement proceeding to enjoin by way of derivative suit the state official who was poised to enforce allegedly unconstitutional rate regulations).

11828 U.S.C. $\$ 2201$ (2006). The Act provides that, in a case of actual controversy within its jurisdiction, and subject to listed exceptions, "any court of the United States, upon the filing of an appropriate pleading, may declare the rights and other legal relations of any interested party seeking such declaration, whether or not further relief is or could be sought." Id.

112 See Aetna Life Ins. Co. v. Haworth, 300 U.S. 227, 239-40 (1937) (requiring an "actual" controversy). Such actions typically face substantial hurdles under doctrines such as standing, ripeness, and abstention, and they are not common. But they do exist and are not impossible to win. Cf. FALLON ET AL., HART AND WeCHSLER, supra note 10, at 725 (acknowledging there is "little clear authority for a general right to obtain anticipatory relief"). Compare, e.g., Seegars v. Gonzalez, 396 F.3d 1248 (D.C. Cir. 2005) (rejecting on justiciability grounds a pre-enforcement challenge to the constitutionality of District of Columbia firearms regulatory statutes), cert. denied, 546 U.S. 1157 (2006), with Nat'l Rifle Ass'n v. Magaw, 132 F.3d 272 (6th Cir. 1997) (permitting portions of such a challenge to the constitutionality of provisions of the federal Violent Crime Control and Law Enforcement Act of 1994 to proceed).

113 If the trial court denies the remedy, the subject may challenge the ruling on appeal or collateral review under procedural mechanisms such as those described in Part II.B.1.c. Obviously, an appeal or collateral attack on the judgment that succeeds in arguing for facial or as-applied nullification of the statute authorizing the underlying enforcement action provides the specific relief that the trial court should have provided. Therefore, such a successful appeal or collateral attack on the judgment differs qualitatively from the successful appeals and collateral attacks that yield substitutionary relief and are described in Part II.B.1.c.

114 I emphasize that the entitlement is to ameliorate violations of individual constitutional rights because the current Supreme Court has recently evinced a reluctance to recognize such 
other than the initiation or imminent initiation of an enforcement action under an unconstitutional law). ${ }^{115}$ As with a damages claim under Bivens, this type of action lies under the constitutional provision in question and 28 U.S.C. $\S 1331$ when it is brought against a federal agent. ${ }^{116}$ When a state agent is the target, 42 U.S.C. $\S 1983$ authorizes the filing of such a claim. ${ }^{117}$

Here again, plaintiffs may avoid any sovereign or Eleventh Amendment immunity bar so long as they seek truly prospective relief against government officials acting in their official capacities. ${ }^{118}$ Webster $v$. Doe $e^{119}$ constitutes a paradigmatic example of such a claim against federal officials. ${ }^{120}$ The lawsuits demanding the structural reform of state and local public institutions, discussed above, ${ }^{121}$ constitute paradigmatic examples of such claims against state officials under Section 1983. Of course, as already mentioned, the remedial decrees in this latter group of cases sometimes contained provisions that went beyond undoing or preventing the constitutional violation that warranted judicial intervention in the first instance. ${ }^{122}$ But to the extent that the decrees also caused the responsible local officials to ameliorate the condition or conditions constituting the ongoing or imminent constitutional violation, whether by refraining from unconstitutional conduct or affirmatively undertaking constitutionally required action, they provided the plaintiffs (or the plaintiff class) with specific relief. Such relief is properly regarded as specific because it has the effect of freeing the plaintiffs from the effects of the ongoing or imminent invasion of their constitutional rights and restoring them to the position they rightfully would have held but for the constitutional violation.

actions to enforce structural constitutional provisions such as the Supremacy Clause. See Stephen I. Vladeck, Douglas and the Fate of Ex Parte Young, 122 YALE L.J. ONLINE 13 (2012), http://www.yalelawjournal.org/images/pdfs/1077.pdf (discussing the implications of Chief Justice Roberts's dissenting opinion in Douglas v. Indep. Living Ctr. of S. Cal., Inc., $132 \mathrm{~S}$. Ct. 1204 (2012), which would have denied the plaintiffs the right to bring an action to enjoin state Medicaid laws that were alleged to have been preempted by the federal Medicaid statute).

115 See supra Part II.B.2.a.

116 See supra note 52 and accompanying text; see also Simmat v. U.S. Bureau of Prisons, 413 F.3d 1225, 1230-33 (10th Cir. 2005) (explaining in detail how and why plaintiffs may seek prospective relief against federal officials for violations of constitutional rights directly under the Constitution pursuant to Section 1331).

117 See supra note 53 and accompanying text. Even prior to the revivification of 42 U.S.C. $\S 1983$ worked by Monroe v. Pape, 365 U.S. 167 (1961), it was understood that actions for prospective relief against state officers to halt ongoing or imminent constitutional violations were available in federal court, see Ex parte Young, 209 U.S. 123 (1908), and in state court, see General Oil Co. v. Crain, 209 U.S. 211 (1908).

118 See supra notes $42 \& 109-10$ and accompanying text.

119486 U.S. 592 (1988).

${ }^{120}$ See id. at 596, 601-05 (seeking specific remedy of reinstatement to employment by federal agency for claimed unconstitutional discrimination on the basis of sexual orientation by federal officials).

121 See supra Part II.B.1.d.

${ }^{122}$ See id. 


\section{c. Habeas Corpus}

The specific remedy of nullification of unconstitutional laws by subjects of government enforcement actions, discussed above, ${ }^{123}$ is available when the government has either formally commenced enforcement proceedings or, if the subject files suit in anticipation of enforcement proceedings, is sufficiently likely to do so to render an anticipatory action justiciable. ${ }^{124}$ But what if the government simply detains an individual without filing charges or providing the individual with access to a judicial officer? In such a situation, the detained individual is constitutionally entitled to access to a judicial officer to contest the detention by means of a petition for a writ of habeas corpus (or any effectual substitute Congress devises). ${ }^{125}$ Habeas corpus is available in such circumstances as a matter of constitutional right so long as (1) Congress has not lawfully suspended its availability, and (2) the petitioner would have had access to the writ under the same or similar circumstances in $1789 .{ }^{126}$ The availability of access to a judicial officer through the writ of habeas corpus ${ }^{127}$ is therefore a specific remedy authorized by the Constitution-one of two such remedies that the Constitution explicitly mentions.

\section{d. "Just Compensation" for Takings}

The other specific remedy that the Constitution explicitly mentions is found in the Just Compensation Clause of the Fifth Amendment. ${ }^{128}$ The Fifth Amendment's Just

123 See supra Part II.B.2.a.

124 See Abbott Labs. v. Gardner, 387 U.S. 136, 148 (1967) (adopting a ripeness standard for evaluating the justiciability of a claim seeking pre-enforcement review).

125 See U.S. CONST. art. I, §9, cl. 2 ("The privilege of the Writ of Habeas Corpus shall not be suspended, unless when in Cases of Rebellion or Invasion the public Safety may require it."); 28 U.S.C. $\$ 2241$ (a) (2006) (authorizing federal Justices and judges to issue writs of habeas corpus).

${ }^{126}$ See Boumediene v. Bush, 128 S. Ct. 2229, 2246-48 (2008) (explaining "“' at the absolute minimum' the [Suspension] Clause protects the writ as it existed when the Constitution was drafted and ratified" (quoting INS v. St. Cyr, 533 U.S. 289, 301 (2001))).

127 This constitutionally contemplated form of habeas corpus, available under 28 U.S.C. $\S 2241$ (2006), should be distinguished from collateral review habeas corpus under 28 U.S.C. $\S 2254$ (2006) (collateral review of state judgments) and 28 U.S.C. $\$ 2255$ (2006) (collateral review of federal judgments). These latter forms of habeas corpus are statutory creations and, as discussed above, usually serve as vehicles for the delivery of substitutionary relief. See supra Part II.B.1.c.

128 See FALlON ET AL., HART AND WECHSLER, supra note 10, at 719 ("The text [of the Constitution] refers explicitly to remedies in only two instances. First, the remedy of habeas corpus is safeguarded against 'suspension' by Congress. Second, the Just Compensation Clause of the Fifth Amendment 'dictates the remedy for interference with property rights amounting to a taking'-compensation for the impairment of value." (citation omitted) (quoting First English Evangelican Lutheran Church v. Cnty. of L.A., 482 U.S. 304, 316 n.9 (1987))). 
Compensation Clause is set forth within its broader Takings Clause, which states that "private property [shall not] be taken for public use, without just compensation."129 It is important to bear in mind that the just compensation mandated by the Takings Clause is not a substitutionary remedy for an earlier, wholly realized constitutional violation. It is, rather, a specific remedy that the government must supply whenever it has "taken" property for public use. ${ }^{130}$ Put another way, the constitutional violation does not occur upon the alleged taking; it takes place only if and when the government fails to provide the "just compensation" that the Constitution mandates in the event of a taking. Thus, a takings claim is in fact a claim for the specific constitutional remedy of "just compensation."

\section{e. A Post-Deprivation Remedy for the Prior Coercive Collection of an} Unconstitutional Tax, Custom, or Duty

There is a distinct class of cases that involve claims for the provision of a postdeprivation remedy for the prior collection of unconstitutional taxes or assessments. The most common such remedy is a tax refund, such as that ordered in Ward v. Love County. ${ }^{131}$ Another remedy, potentially available in cases where a tax is held to violate equal protection or dormant commerce clause principles by treating plaintiffs unfairly vis-à-vis another class of taxpayers, is the retroactive imposition of an equalizing tax on the previously favored taxpayers, such as that discussed in McKesson Corp. $v$. Division of Alcoholic Beverages \& Tobacco. ${ }^{132}$ Some combination of the two also is permissible. ${ }^{133}$

Claims for the provision of a post-deprivation tax remedy should be distinguished from claims in which a taxpayer seeks the specific remedy of nullification of an unconstitutional tax or the specific remedy of injunctive or declaratory relief invalidating the unconstitutional tax itself. ${ }^{134}$ Claims for post-deprivation relief of the sort

129 U.S. CONST. amend. V.

130 See Williamson Cnty. Reg'l Planning Comm'n v. Hamilton Bank, 473 U.S. 172, 194 (1985) (observing that the Takings Clause "does not proscribe the taking of property; it proscribes taking without just compensation").

131 See 253 U.S. 17 (1920) (ordering a county to refund monies paid under a tax that the county commissioners lacked the constitutional power to enforce).

132 See 496 U.S. 18 (1990) (holding that the remedy for such a tax should be either a refund of the constitutionally excessive portion of the taxes paid or, to the extent otherwise consistent with the Constitution, the assessment and collection of back taxes on the previously favored class).

133 See id. at $39-41$.

134 See supra Parts II.B.2.a-b. Such claims are often precluded by statute. State law frequently requires taxpayers who object to a tax on constitutional grounds to pay first and to litigate later, see FALLON ET AL., HART AND WECHSLER, supra note 10, at 1043, and the federal Tax Injunction Act prohibits federal courts from interfering with such state schemes, see 28 U.S.C. $\S 1341$ (2006) (limiting federal court jurisdiction to enjoin the collection of state 
described in this subsection can of course be joined with claims attacking the constitutionality of the tax itself (when such claims are permitted). ${ }^{135}$ But the claims themselves are separate and distinct, and a claimant's entitlement to a means for obtaining a remedy, notwithstanding sovereign immunity, is separately rooted in the constitutional guarantee of due process. ${ }^{136}$

Why should a claim seeking a post-deprivation remedy for the prior coercive collection of an unconstitutional tax be regarded as seeking specific rather than substitutionary relief, given that the unlawful assessment and coercive collection are wholly concluded at the time the taxpayer seeks a post hoc remedy? The answer lies in the fact that the Supreme Court has identified the due process guarantee, and not the constitutional provision that the unlawful tax violated, as the source of the taxpayer's entitlement to a remedy. ${ }^{137} \mathrm{~A}$ taxpayer who has paid an unconstitutional tax and is seeking a post-deprivation remedy as a matter of constitutional right- because the taxing entity has not provided her with a positive law mechanism for obtaining post-deprivation

taxes); see also infra Part III.B.1. Moreover, the federal tax Anti-Injunction Act, 26 U.S.C. $\S 7421$ (a) (2006), prohibits any "suit for the purpose of restraining the assessment or collection of any tax" unless the suit falls within one of fourteen specified exceptions.

${ }^{135}$ See, e.g., Iowa-Des Moines Nat'l Bank v. Bennett, 284 U.S. 239 (1931) (involving (1) a claim that a tax on stock violated the Equal Protection Clause because it was higher than the tax imposed on the stock of competing domestic corporations, and (2) a separate request for a refund of the unconstitutionally excessive portion of the tax).

136 See Reich v. Collins, 513 U.S. 106, 109-10 (1994) (observing that "a denial by a state court of a recovery of taxes exacted in violation of the laws or Constitution of the United States by compulsion is itself in contravention of the Fourteenth Amendment, the sovereign immunity States traditionally enjoy in their own courts notwithstanding" (citation omitted) (internal quotation marks omitted)); see also id. at 110 (noting that "the sovereign immunity States enjoy in federal court, under the Eleventh Amendment, does generally bar tax refund claims from being brought in that forum" (citing Ford Motor Co. v. Dep't of Treasury of Ind., 323 U.S. 459 (1945))).

In Alden v. Maine, 527 U.S. 706 (1999), which held that Congress may not subject states to suit in their own courts absent their consent, the majority gave the recently and unanimously decided Reich a mysteriously narrow reading. The majority characterized the case as having held only that,

[D]espite its immunity from suit in federal court, a State which holds out what plainly appears to be "a clear and certain" postdeprivation remedy for taxes collected in violation of federal law may not declare, after disputed taxes have been paid in reliance on this remedy, that the remedy does not in fact exist.

Id. at 740. For a discussion of how to read Reich in light of Alden, see FALLON ET AL., HART AND WECHSLER, supra note 10 , at 721 .

${ }^{137}$ Litigation has focused on the constitutionality of state rather than federal schemes because federal law provides a refund remedy pursuant to the Tucker Act, 28 U.S.C. $§ 1491$ (a)(1)(2006). See United States v. Clintwood Elkhorn Mining Co., 128 S. Ct. 1511, 1514-15 (2008)(detailing how a taxpayer forced to pay an unlawful federal tax must seek a refund administratively before suing the government for a refund under the Tucker Act). 
relief on its own-is not making a direct claim for a substitutionary remedy for the effects of the unconstitutional tax under Bivens or Section 1983. She is, rather, seeking a constitutional entitlement that is being withheld as an ongoing matter: the due process guarantee of an effective post-deprivation remedy for persons in her position. And as we have seen, a request for a constitutional entitlement that is being withheld as an ongoing matter is a request for a specific constitutional remedy.

\section{Summary}

From the discussion above, we see that there is a strong correlation between the discretionary acts of individual government agents who violate the Constitution and substitutionary constitutional remedies. Because such discretionary acts usually cannot be challenged in real time or in advance of their occurrence, ${ }^{138}$ the violation is typically wholly realized by the time the affected party challenges it in court. And remedies for wholly realized constitutional violations are by their nature substitutionary. ${ }^{139}$

By contrast, we see a nearly perfect identity between ongoing unconstitutional governmental policies and customs - governmental positions taken in statutes, regulations, informal policy, and through the modus operandi of those who function as government policymakers - and specific constitutional remedies. Specific constitutional remedies are by their nature available to address only ongoing or imminent violations, and not violations that are wholly concluded. In the constitutional law context, such ongoing or imminent violations are almost invariably worked by policies and customs rising to the level of unconstitutional "law," and not the discretionary unconstitutional "conduct" of government agents. Thus, we may generalize that specific constitutional remedies are the typical means by which courts directly ${ }^{140}$ halt ongoing or imminent

${ }^{138}$ Limitations on the standing doctrine make anticipatory challenges of this sort nearly impossible. See City of L.A. v. Lyons, 461 U.S. 95 (1983) (denying standing to a victim of an allegedly unconstitutional chokehold to bring a prospective challenge against the legality of the practice).

139 There are exceptions to the generalization that claims for substitutionary relief target wholly realized wrongs. For example, a suit for money damages against a municipality under Section 1983 is a claim for substitutionary relief to compensate for harm caused not by the wholly realized discretionary act of a government agent, but for the harm caused by an unconstitutional custom or policy that may well be causing ongoing harm to the right-holder. See supra notes 52-60 and accompanying text. So too may a claim for substitutionary relief target an unconstitutional law and not discretionary conduct. See, e.g., United States v. Booker, 543 U.S. 220 (2005) (authorizing reversals of criminal convictions affected by unconstitutional provisions of the U.S. Sentencing Guidelines).

140 I say "directly" because a substitutionary remedy can indirectly cause government authorities to cease and desist in enforcing an unconstitutional policy or custom. For example, a damage award that compensates a plaintiff for harm done by an unconstitutional municipal custom or policy, see, e.g., supra note 139, would doubtless lead to a cessation of the policy in question, even in the absence of a concomitant injunction striking down the custom or policy. 
violations of constitutional rights, which usually take place in the form of some sort of unconstitutional law (broadly defined) affecting the liberty or property interests of the right-holder.

\section{THE WITHHOLDING OF CONSTITUTIONAL REMEDIES}

\section{A. Doctrines Limiting the Availability of Substitutionary Constitutional Remedies}

For each type of substitutionary constitutional remedy available to ameliorate a wholly realized constitutional wrong, the Supreme Court has developed one or more doctrines that require courts to withhold remedies in circumstances where there has been a violation of rights. And in each case, the Court has been clear that the limits it is imposing are rooted in public interest balancing. ${ }^{141}$

\section{Individual Immunity Doctrines}

It is well known that the availability of damages remedies from agents of the federal government under Bivens, ${ }^{142}$ and from agents of state and local governments pursuant to 42 U.S.C. $\S 1983,{ }^{143}$ is significantly circumscribed. ${ }^{144}$ As an initial matter, a number of public officials simply do not qualify as persons subject to a claim for damages under Bivens or Section 1983; they are said be cloaked in absolute immunity. ${ }^{145}$ As matters presently stand, absolute immunity protects legislators acting in a legislative capacity, ${ }^{146}$ judges acting in a judicial capacity, ${ }^{147}$ prosecutors acting in a prosecutorial capacity, ${ }^{148}$ grand jurors, ${ }^{149}$ and witnesses. ${ }^{150}$

141 Obviously, by definition, provisions of structural reform injunctions that are unnecessary to prevent or undo a constitutional violation do not themselves "remedy" a violation of rights, at least directly. Thus, they differ qualitatively from the other substitutionary constitutional remedies discussed above. But such provisions, if permissible at all under modern doctrine, are certainly also subject to public interest balancing. See infra Part III.A.5. So in this respect, they are like their substitutionary remedial counterparts.

142 See supra Part II.B.1.a.

143 See supra Part II.B.1.a.

144 In this subsection, I focus on doctrines that limit the availability of a damages remedy even where a Bivens claim is authorized. But as noted above, since 1980, the Supreme Court has put a number of additional restrictions on the availability of the Bivens damages remedy. See supra note 52.

145 See Greabe, supra note 61, at 36-37.

146 See Tenney v. Brandhove, 341 U.S. 367, 379 (1951).

147 See Pierson v. Ray, 386 U.S. 547, 554-55 (1967).

148 See Imbler v. Pachtman, 424 U.S. 409, 417-20 (1976).

149 See id. at 423 n.20.

150 See Rehberg v. Paulk, 132 S. Ct. 1497 (2012) (grand jury witness); Briscoe v. LaHue, 460 U.S. 325, 335 (1983) (trial witness). 
In addition, those government actors who are not protected by absolute immunity are entitled to a qualified immunity from suit and damages liability under Bivens and Section 1983. Qualified immunity was originally formulated as a doctrine that protected individual government actors from liability when their conduct, although in violation of the Constitution, met two relatively demanding requirements: (1) there existed objectively reasonable grounds for the defendant to conclude that the challenged action was lawful "at the time and in light of all the circumstances,"151 and (2) the defendant acted in "good faith" and with a sincere belief that he was doing right. ${ }^{152}$ But in 1982, the Supreme Court decided Harlow v. Fitzgerald, ${ }^{153}$ which eliminated the requirement of subjective good faith and transformed the doctrine into one that protects all defendants whose conduct was objectively reasonable in light of "clearly established" law at the time that it was undertaken. ${ }^{154}$ The Harlow Court was candid in explaining that it was changing the law because of an overriding policy consideration: a perceived need to secure quicker dismissals of civil rights claims so that government actors would not be over-deterred in performing their duties by the threats of burdensome discovery and having to face unmeritorious claims at trial. ${ }^{155}$ In subsequent years, the Court expanded the reach of the doctrine by emphasizing its broad scope ${ }^{156}$ and insisting that courts define rights at a very high level of specificity in determining whether they are "clearly established." 157

Finally, the Court has also strongly suggested, although it has not held, that private parties who are not government actors, but who nonetheless stand accused of unconstitutionally exercising government power under the state action doctrine, may be entitled to avoid liability through a "good faith" defense. ${ }^{158}$ Private parties are not entitled to assert the specialized qualified immunity defense available to government

151 Gomez v. Toledo, 446 U.S. 635, 641 (1980) (quoting Scheuer v. Rhodes, 416 U.S. 232, $247-48$ (1974)).

152 Id.

153457 U.S. 800 (1982).

154 See id. at 814-19 (explaining that immunity should extend to all "government officials performing discretionary functions ... insofar as their conduct does not violate clearly established ... constitutional rights of which a reasonable person would have known").

155 See id.

156 See Malleyv. Briggs, 475 U.S. 335, 341 (1986)(stating that qualified immunity "provides ample protection to all but the plainly incompetent or those who knowingly violate the law").

157 See Anderson v. Creighton, 483 U.S. 635, 639-40 (1987) (emphasizing that, for a right to be clearly established, its contours "must be sufficiently clear that a reasonable official would understand that what he is doing violates that right"). As Professor Alan Chen has shown, the Court's initial justification for the immunity doctrines-avoiding the over-deterrence of public officials - has in recent years morphed into a more general concern about the social costs of civil rights litigation. See Alan K. Chen, The Facts About Qualified Immunity, 55 EMORY L.J. 229, 236-37 (2006).

158 See Richardson v. McKnight, 521 U.S. 399, 413-14(1997); Wyatt v. Cole, 504 U.S. 158, 163-69 (1992). 
actors. ${ }^{159}$ But such a good faith defense would likely overlap substantially, and perhaps be coextensive with, the qualified immunity defense. ${ }^{160}$

Because many of the cases in which these immunity doctrines were identified involved claims under Section $1983,{ }^{161}$ one might question whether it is appropriate to label the resultant doctrines as products of judicial lawmaking rooted in public interest balancing and not liability limits evident in, or inferable from, the text of the statute itself. But these doctrines cannot plausibly be seen as interpretations of Section 1983. First, many of the most important doctrinal developments in individual immunity law have occurred in the non-statutory Bivens context and then simply been applied to damages claims under Section $1983 .{ }^{162}$ Second, the Court has itself acknowledged that Section 1983 "creates a species of tort liability that on its face admits of no immunities," 163 and it has explained its immunity doctrines in terms that heavily emphasize the vital role played by public interest concerns: "[W]e have accorded certain government officials . . . immunity . . . if the 'tradition of immunity was so firmly rooted in the common law and was supported by such strong policy reasons that Congress would have specifically so provided had it wished to abolish the doctrine." "164 Third, and most importantly, the Court has been clear that, in elaborating the scope of these immunities, it sees itself as free to advance the perceived public interest; it is not constrained by the dictates of history and the traditions on which the immunities are loosely based. ${ }^{165}$ The individual immunity doctrines that limit the recovery of damages

159 See Wyatt, 504 U.S. at 166-69; see also Filarsky v. Delia, 132 S. Ct. 1657, 1666-68 (2012) (noting the distinction between those who work for the government and "private" individuals subject to liability under Bivens and Section 1983, and applying an expansive interpretation of the former category).

${ }^{160}$ See Wyatt, 504 U.S. at 168-69.

161 See, e.g., Richardson, 521 U.S. 399; Wyatt, 504 U.S. 158.

162 For example, Harlow's reformulation of qualified immunity into a wholly objective inquiry took place in the context of a Bivens claim. See Harlow v. Fitzgerald, 457 U.S. 800, 805 (1982). Also, the de facto (although unexplained) transformation of qualified immunity from an affirmative defense into a doctrine whose inapplicability must be established as an element of a civil rights damages claim was accomplished in a pair of recent, high profile Bivens actions: Ashcroft v. Iqbal, 129 S. Ct. 1937 (2009), and Ashcroft v. al-Kidd, 131 S. Ct. 2074 (2011). For an explanation of how Iqbal and al-Kidd worked this transformation, see Greabe, supra note 61 , at $7-22$.

163 Wyatt, 504 U.S. at 163 (quoting Imbler v. Pachtman, 424 U.S. 409, 417 (1976)).

164 Id. at 163-64 (emphasis added) (quoting Owen v. City of Independence, 445 U.S. 622, 637 (1980)) (internal quotation marks omitted).

165 See Anderson v. Creighton, 483 U.S. 635, 644-45 (1987) (“Although it is true that we have observed that our determinations as to the scope of official immunity are made in the light of the 'common-law tradition,' we have never suggested that the precise contours of official immunity can and should be slavishly derived from the often arcane rules of the common law. That notion is plainly contradicted by Harlow, where the Court completely reformulated qualified immunity along principles not at all embodied in the common law ...." (citation omitted)). 
in Bivens and Section 1983 actions are thus clearly the product of judicial lawmaking rooted in public interest balancing.

\section{Exceptions to the Exclusionary Rule}

As discussed above, the Supreme Court has developed an exclusionary rule that presumptively requires the suppression of evidence that was obtained in violation of the Fourth Amendment's ban on unreasonable searches and seizures. ${ }^{166}$ The purpose of the rule is, of course, to deter government officials from disregarding Fourth Amendment rights. ${ }^{167}$ But the Court also has held that exclusion pursuant to the rule is not a personal constitutional right of the accused and is not inevitably warranted. ${ }^{168}$ The Court has repeatedly invoked this latter proposition to justify a number of "exceptions" to the rule: the "good faith" exceptions recognized in United States v. Leon, ${ }^{169}$ Illinois v. Krull, ${ }^{170}$ Arizona v. Evans, ${ }^{171}$ and Davis v. United States, ${ }^{172}$ the broader good-faith principle recently recognized in Herring $v$. United States; $;{ }^{173}$ and the exception for violations of the "knock-and-announce" rule recognized in Hudson v. Michigan. ${ }^{174}$

166 See supra notes $70 \& 74-75$ and accompanying text. I focus in this subsection on exceptions to the Fourth Amendment's exclusionary rule because the withholding of the substitutionary constitutional remedy of exclusion has occurred most frequently in the Fourth Amendment context. I note, however, that the Supreme Court also recently authorized an exception to the rule requiring the exclusion of evidence obtained in violation of the Sixth Amendment right to counsel recognized in Massiah v. United States, 377 U.S. 201 (1964), see supra notes 76 \& 79 and accompanying text, when such evidence is used for impeachment purposes at trial. See Kansas v. Ventris, 556 U.S. 586, 593-94 (2009).

167 See United States v. Calandra, 414 U.S. 338, 347-48 (1974) (emphasizing that the exclusionary rule's purpose is to deter police misconduct).

168 See id.

169468 U.S. 897 (1984) (authorizing the admission of evidence obtained by police officers who reasonably rely on a faulty warrant).

170480 U.S. 340 (1987) (authorizing the admission of evidence obtained pursuant to searches conducted in reasonable reliance on subsequently invalidated statutes).

171514 U.S. 1 (1995) (authorizing the admission of evidence obtained in circumstances where police reasonably relied on erroneous information concerning an arrest warrant in a database maintained by judicial employees).

172131 S.Ct. 2419 (2011)(authorizing admission of evidence obtained where police reasonably relied on binding judicial precedent).

173129 S. Ct. 695 (2009) (authorizing the admission of evidence obtained through a merely negligent disregard of Fourth Amendment rights, and holding that exclusion should follow only police conduct that can be described as deliberate, reckless, or grossly negligent —or that can be traced to recurring or systemic negligence - with respect to Fourth Amendment rights).

174547 U.S. 586 (2006) (holding that a violation of the Fourth Amendment's "knock-andannounce" rule does not require exclusion of the evidence found in the search that followed the violation). 
Moreover, in Stone v. Powell, ${ }^{175}$ the Court held that Fourth Amendment violations cannot ground the reversal of a state criminal judgment under 28 U.S.C. $\S 2254$ if the petitioner had a full and fair opportunity to litigate the Fourth Amendment claim in state court. ${ }^{176}$

In each instance, the Court explained that its decision to withhold a remedy for the underlying Fourth Amendment violation was the product of cost-benefit policy analysis. In Leon, for example, the Court stated that its decision was grounded in a conclusion that the "substantial costs of exclusion" would outweigh the "marginal or nonexistent benefits produced by suppressing evidence obtained in objectively reasonable reliance on a subsequently invalidated search warrant." ${ }^{, 177}$ Similar explanations, all involving conclusions that the costs of exclusion would outweigh its likely deterrent effect, may be found in Krull, ${ }^{178}$ Evans, ${ }^{179}$ Herring, ${ }^{180}$ Hudson, ${ }^{181}$ and Davis. ${ }^{182}$ The same is so with Stone, which held that the utility of exclusion did not outweigh the costs of extending it to collateral review. ${ }^{183}$ Thus, doctrines carving out exceptions to the exclusionary rule also involve the withholding of substitutionary constitutional remedies under public interest balancing.

\section{Harmless Error Doctrines}

The Supreme Court has developed two harmless error rules that regulate the availability of relief to those who seek reversal of a judgment affected by constitutional trial error on direct or collateral review. ${ }^{184}$ On direct review, under the rule adopted in Chapman v. California, a constitutional trial error requires reversal unless "the

\footnotetext{
175428 U.S. 465 (1976).

176 Id.

177 United States v. Leon, 468 U.S. 897, 922 (1984).

178 Illinois v. Krull, 480 U.S. 340, 352-53 (1987).

179 Arizona v. Evans, 514 U.S. 1, 14-16 (1995).

180 Herring v. United States, 129 S. Ct. 695, 699-701 (2009).

181 Hudson v. Michigan, 547 U.S. 586, 591-94 (2006).

182 Davis v. United States, 131 S. Ct. 2319, 2426-27 (2011).

183 Stone v. Powell, 428 U.S. 465, 489-95 (1976).

184 In this context, constitutional trial error must be differentiated from structural constitutional error. See Arizona v. Fulminante, 499 U.S. 279, 306-10 (1991) (dividing constitutional errors into these two classes); see also United States v. Gonzalez-Lopez, 548 U.S. 140,149 (2006) (listing as recognized structural errors the denial of counsel (citing Gideon v. Wainwright, 372 U.S. 335(1963)), the denial of the right of self-representation (citing McKaskle v. Wiggins, 465 U.S. 168, 177-78, n.8 (1984)), the denial of the right to public trial (citing Waller v. Georgia, 467 U.S. 39, 49, n.9 (1984)), and the denial of the right to trial by jury by the giving of a defective reasonable-doubt instruction (citing Sullivan v. Louisiana, 508 U.S. 275 (1993))); id. at 150 (adding denial of the right of counsel of choice to the list of recognized structural errors). A judgment infected by such structural error is not subject to harmless error review. See Fulminante, 499 U.S. at 309-10.
} 
beneficiary of [the] error [proves] beyond a reasonable doubt that the error complained of did not contribute to the verdict obtained." ${ }^{185}$ On collateral review, under the rule adopted in Brecht v. Abrahamson, ${ }^{186}$ such an error requires reversal only if the petitioner establishes that it had a "substantial and injurious effect or influence in determining the jury's verdict." 187

The Court developed both rules as limits on the availability of the substitutionary constitutional remedy of reversal of a conviction tainted by constitutional error. Prior to the time the Court handed down Chapman, it was generally understood that constitutional trial errors required automatic reversal. ${ }^{188}$ Prior to Brecht, it was understood that the Chapman rule should govern the availability of collateral relief for constitutional trial errors. ${ }^{189}$

Chapman and Brecht both used cost-benefit policy analysis to explain the limitations on the availability of substitutionary relief that they imposed. In Chapman, the Court quite briefly justified its adoption of a harmless error rule for constitutional errors by stating that harmless error rules "serve a very useful purpose insofar as they block setting aside convictions for small errors or defects that have little, if any, likelihood of having changed the result of the trial. ${ }^{, 190}$ In Brecht, the Court candidly acknowledged that its choice of the more forgiving Kotteakos harmless error standard ${ }^{191}$ was a consequence of its having concluded that there was an "imbalance of ... costs and benefits" in applying the Chapman rule on collateral review. ${ }^{192}$ Accordingly, both rules stand

185 386U.S. 18,24 (1967). The Chapman rule only applies to those who have preserved their appellate rights. Otherwise, an unforgiving "plain error" standard applies. See supra note 94.

186507 U.S. 619 (1993).

187 Id. at 637 (quoting Kotteakos v. United States, 328 U.S. 750, 776(1946)). Brecht adopted the harmless error standard prescribed in Kotteakos for review of constitutional trial errors on collateral review which elaborated on the meaning of a federal harmless error statute applicable to non-constitutional trial errors. Id. That statute, now codified at 28 U.S.C. $\S 2111$ (2006), directs courts to disregard errors or defects "which do not affect the substantial right of the parties." See Goldblatt, supra note 26, at 998-99 (explaining why Section 2111 does not apply to constitutional trial errors).

188 See Charles J. Ogletree, Jr., Comment, Arizona v. Fulminante: The Harm of Applying Harmless Error to Coerced Confessions, 105 HARV. L. REV. 152, 157 \& n.43 (1991) (collecting cases); see also Goldblatt, supra note 26, at 995; John M. Greabe, Spelling Guilt Out of a Record? Harmless-Error Review of Conclusive Mandatory Presumptions and Elemental Misdescriptions, 74 B.U. L. REV. 819, 825 (1994); Sam Kamin, Harmless Error and the Rights/Remedies Split, 88 VA. L. REV. 1, 10-11 (2002).

189 See Greabe, supra note 188 , at $829 \&$ n.69 (collecting cases).

190386 U.S. at 22; see also id. at 22-24 (explaining the adoption of the "beyond a reasonable doubt" standard in policy terms).

191 See supra note 186.

192 Brecht, 507 U.S. at 637; see also id. at 635-36 (emphasizing that "the State's interest in the finality of convictions that have survived direct review," comity, federalism, and the interest in maintaining the prominence of the trial itself all militate in favor of a more lenient harmless error rule on collateral review than the rule that applies on direct review). 
as additional examples of the Court fashioning doctrines that withhold substitutionary constitutional remedies under reasoning rooted in public interest balancing.

\section{The Non-Retroactivity Principle of Teague v. Lane}

The non-retroactivity principle of Teague $v$. Lane $e^{193}$ is much the same. The Teague principle is best understood in the context of the development of the law of retroactivity in criminal procedure. Traditionally, judicial decisions creating new law were applied retroactively to the parties and to other litigants in pending cases that had not yet become "final." "194 The Warren Court, however, developed criminal procedure doctrines that permitted it to render constitutional decisions that would not apply retroactively in certain circumstances. ${ }^{195}$ Justice Harlan strongly criticized these doctrines ${ }^{196}$ and argued that courts should apply all decisions retroactively on direct review. ${ }^{197} \mathrm{He}$ conceded, however, that a state's policy interest in finality almost always trumps this imperative on collateral review. ${ }^{198} \mathrm{He}$ thus engaged in a form of cost-benefit analysis to suggest that new decisions should apply retroactively on collateral review only where the decision (1) holds "previously punishable conduct to be constitutionally protected," or (2) recognizes a right of procedure that is "so fundamental as to be "implicit in the concept of ordered liberty." "199

Justice Harlan's position ultimately prevailed. In Griffith $v$. Kentucky, ${ }^{200}$ the Court held that all new rules of criminal procedure should be fully retroactive on direct review. ${ }^{201}$ And in Teague, the Court effectively accepted the Justice's policy

193489 U.S. 288 (1989).

194 FALLON ET AL., HART AND WECHSLER, supra note 10, at 1241 (explaining that "“final' means that certiorari has been denied or that the time for seeking [additional direct] appellate review has expired").

${ }_{195}$ See id. (discussing Linkletter v. Walker, 381 U.S. 618 (1965), which declined to apply the Mapp rule to convictions that became final before Mapp was decided; Johnson v. New Jersey, 384 U.S. 719 (1966), which declined to apply the Miranda rules to trials that commenced before Miranda was decided; and Stovall v. Denno, 388 U.S. 293 (1967), overruled on other grounds, 479 U.S. 314 (1987), which developed a retroactivity test that looked to "the purpose of the new rule, the extent of reliance on the old rule, and the effect on the administration of justice of retroactive application of the new rule").

196 See id. at 1241-42 (discussing Justice Harlan's separate opinions in Desist v. United States, 394 U.S. 244, 256-69 (1969), and Mackey v. United States, 401 U.S. 667, 675-702 (1971)).

197 See id. at 1242.

198 See id.

199 See id. Note that the first of these exceptions preserves the right to seek the one form of specific relief available on collateral review. See supra note 113 and accompanying text; see also infra Part IV (hypothesizing that specific constitutional relief is at least presumptively mandatory).

200479 U.S. 314 (1987).

201 See id. at 320-28; see also FALLON ET AL., HART AND WECHSLER, supra note 10, at 1242. A retroactivity principle analogous to that announced in Griffith has been recognized 
judgment with respect to collateral review. ${ }^{202}$ Teague thus stands as yet another example of judicial lawmaking rooted in public interest balancing that limits the availability of substitutionary constitutional remedies. ${ }^{203}$

\section{Constraints on Provisions of Structural Reform Injunctions That Are} Unnecessary to Prevent or Undo a Constitutional Violation

As discussed above, it is at best debatable under recent doctrine whether courts ever may issue structural reform injunctions that contain provisions that do more than just prevent or undo the constitutional violation that justified judicial intervention. ${ }^{204}$ Thus, we may safely generalize that courts never should approve of such provisions in circumstances where their benefits are outweighed by their likely adverse impact on the public interest. In other words, such provisions are plainly subject to being withheld from remedial decrees under public interest balancing.

\section{B. Doctrines Limiting the Availability of Specific Constitutional Remedies}

In contrast to the limits on the availability of substitutionary constitutional remedies discussed above, the Supreme Court has not authorized the withholding of specific constitutional remedies on grounds of public interest balancing. ${ }^{205}$ In fact, the Court has recognized only a few legitimate limits on the availability of specific constitutional remedies for invasions of rights. And in each case, the recognized limits are rooted in structural federalism and separation of powers concerns that compete with, and sometimes

in the context of tax remedies as well. See Harper v. Virginia Dep't of Taxation, 509 U.S. 86, 89-90 (1993) (announcing that the constitutional ruling in Davis v. Michigan Dep't of Treasury, 489 U.S. 803 (1989), must apply retroactively). Moreover, in Reynoldsville Casket Co. v. Hyde, 514 U.S. 749 (1995), the Court cast doubt on the permissibility of invoking remedial discretion to deny relief for the violation of a new constitutional rule in any context other than one in which there is some other policy reason for doing so. For a summary of Harper and Reynoldsville Casket, and for a suggestion that the principle articulated in the latter case is ultimately incoherent, see FALLON ET AL., HART AND WECHSLER, supra note 10, at 721-23.

${ }^{202}$ See Teague v. Lane, 489 U.S. 288, 305-14 (1989) (O'Connor, J., plurality). Justice O'Connor accepted Justice Harlan's position but reformulated his second exception into one that holds that "a habeas court may apply a new rule that implicates the fundamental fairness of the trial" and is necessary to prevent a serious diminishment of the likelihood of an accurate conviction); FALLON ET AL., HART AND WECHSLER, supra note 10, at 1242. The Court has endorsed and followed this opinion in numerous subsequent decisions. Id. For a comprehensive overview of Teague and the questions it raises, see id. at 1242-48.

${ }^{203}$ In 1996, Congress enacted the Antiterrorism and Effective Death Penalty Act, which imposed a relitigation bar that resembles but is distinct from the Teague rule. See 28 U.S.C. $\S 2254(d)$ (2006) (codifying the relitigation bar); Horn v. Banks, 536 U.S. 266 (2002) (per curiam) (clarifying that the statutory and Teague inquiries are distinct).

204 See supra note 103 and accompanying text.

205 See supra notes 9-10 and accompanying text. 
trump, the powerful norm that courts should freely grant specific remedies to ameliorate ongoing or imminent violations of constitutional rights.

\section{Judicial Federalism Doctrines}

The Supreme Court has identified a number of circumstances in which lower federal courts should not provide litigants with a remedy-specific or otherwise-even if a claimant can establish an ongoing or imminent violation of her constitutional rights. Sometimes, lower federal courts must decline to proceed because Congress has imposed limitations on federal court intrusion into pending state court proceedings. Examples of such statutory limitations include the federal Anti-Injunction Act, ${ }^{206}$ the Johnson Act of $1934,{ }^{207}$ and the Tax Injunction Act of $1937 .{ }^{208}$

Moreover, the Court has itself developed a number of federalism doctrines that work to limit lower federal court jurisdiction over claims that fall within the literal terms of congressional grants of jurisdiction. ${ }^{209}$ Some but not all of these doctrines can operate to deflect from federal court jurisdiction justiciable claims for specific relief for ongoing or imminent constitutional infringements that, absent federalism concerns, would be entirely appropriate for federal adjudication. ${ }^{210}$ Examples of doctrines that

206 The Anti-Injunction Act, 28 U.S.C. $\$ 2283$ (2006), provides: “A court of the United States may not grant an injunction to stay proceedings in a State court except as expressly authorized by Act of Congress, or where necessary in aid of its jurisdiction, or to protect or effectuate its judgments." For a comprehensive discussion of the Act, its history, and its recognized exceptions, see FALLON ET AL., HART AND WECHSLER, supra note 10, at 1019-41.

207 The Johnson Act of 1934, 28 U.S.C. $\$ 1342$ (2006), provides:

The district courts shall not enjoin, suspend or restrain the operation of, or compliance with, any order affecting rates chargeable by a public utility and made by a State administrative agency or a rate-making body of a State political subdivision, where:

(1) Jurisdiction is based solely on diversity of citizenship or repugnance of the order to the Federal Constitution; and,

(2) The order does not interfere with interstate commerce; and,

(3) The order has been made after reasonable notice and hearing; and,

(4) A plain, speedy and efficient remedy may be had in the courts of such State.

For a discussion of the Johnson Act of 1934, including an extension of its proscriptions to declaratory judgment and damages actions, see FALLONET AL., HART AND WECHSLER, supra note 10 , at $1042-43$.

208 The Tax Injunction Act of 1937, 28 U.S.C. $\$ 1341$ (2006), provides: "The district courts shall not enjoin, suspend, or restrain the assessment, levy or collection of any tax under State law where a plain, speedy, and efficient remedy may be had in the courts of such State." See also supra note 134. For a discussion of the scope and breadth of the Tax Injunction Act, including how its proscriptions have been extended to declaratory judgment and damages actions in both federal and state court, see FALLON ET AL., HART AND WECHSLER, supra note 10, at 1043-49.

209 See FAllON ET AL., HART AND WECHSLER, supra note 10, at 1049-151, 1311-53.

210 For example, there is a recognized doctrine that requires exhaustion of state nonjudicial remedies. See $i d$. at 1050-57. But this doctrine generally does not apply to actions under 42 
can so operate include: Pullman abstention, ${ }^{211}$ Younger abstention, ${ }^{212}$ and the RookerFeldman doctrine. ${ }^{213}$

It bears emphasis that each of these doctrines, whether statutory or judicially created, is rooted in a constitutional imperative-federalism - that competes with the ubi jus, ibi remedium principle. ${ }^{214}$ In other words, these doctrines are not grounded in concerns about any adverse effects that the specific constitutional remedy requested might have on the public interest. Moreover, and importantly, these doctrines do not authorize the withholding of relief altogether, as do the doctrines discussed above in connection with substitutionary constitutional remedies. ${ }^{215}$ At most, they sometimes require that claimants forgo immediate specific remedies from a federal court and

U.S.C. $\S 1983$, see id. at 1052-53 (discussing Patsy v. Bd. of Regents, 457 U.S. 496 (1982)), although there are a few recognized exceptions to the Patsy rule. See id. at 1054-56.

${ }^{211}$ See R.R. Comm'n v. Pullman Co., 312 U.S. 496(1941)(holding that federal courts should abstain from adjudicating the constitutionality of state enactments fairly open to interpretation until the state courts have been afforded a reasonable opportunity to pass on them). For a comprehensive discussion of Pullman abstention and related doctrines, including a note explaining that Pullman abstention applies to actions under 42 U.S.C. $§ 1983$, and a note on abstention under Burford v. Sun Oil Co., 319 U.S. 315 (1943) (authorizing abstention where a federal action challenges certain state administrative action subject to timely and adequate state court review) and Louisiana Power \& Light Co. v. City of Thibodaux, 360 U.S. 25 (1959) (authorizing abstention where a federal action implicates difficult questions of state law bearing on important state policy problems whose import transcends the underlying case), see FALLON ET AL., HART AND WECHSLER, supra note 10, at 1057-83.

${ }_{212}$ See Younger v. Harris, 401 U.S. 37 (1971) (holding that federal courts should abstain from hearing constitutional challenges that can be raised in a pending state court criminal prosecution). For a comprehensive discussion of Younger and related doctrines, including the restriction of Younger to pending cases under the rule recognized in Steffel $v$. Thompson, 415 U.S. 452 (1974), the limitation on Steffel recognized in Hicks v. Miranda, 422 U.S. 332 (1975) (holding that the federal court should abstain if the state initiates criminal proceedings after the initiation of the federal action but before any proceedings of substance on the merits have taken place in federal court), and the extension of Younger to the civil context, see FALLON ET AL., HART AND WECHSLER, supra note 10, at 1083-128.

213 The so-called Rooker-Feldman doctrine, named for Rooker v. Fidelity Trust Co., 263 U.S. 413 (1923), and District of Columbia Court of Appeals v. Feldman, 460 U.S. 462 (1983), prohibits parties subject to adverse state-court judgments rendered before federal proceedings were commenced from receiving relief from those judgments in federal court other than by means of a petition for a writ of certiorari to the Supreme Court under 28 U.S.C. $§ 1257$ (2006). See Exxon Mobil Corp. v. Saudi Basic Indus. Corp., 544 U.S. 280 (2005). For a discussion of the Rooker-Feldman doctrine, see FALLON ET AL., HART AND WECHSLER, supra note 10 , at $1346-53$.

214 See supra note 13 and accompanying text.

215 See also id. at 1937 (observing that a reading of the Prison Litigation Reform Act of 1995, 18 U.S.C. $\$ 3626$ (2006), that would preclude a remedy for unconstitutional prison overcrowding "would raise serious constitutional concerns" (citing Bowen v. Mich. Acad. of Family Physicians, 476 U.S. 667, 681 n.12 (1986))); cf. Brown v. Plata, 131 S. Ct. 1910, 1947 (2011) (observing that the ongoing constitutional violation of prison overcrowding "requires a remedy"). 
instead seek relief from a state court—substitutionary or specific - that cannot be withheld as a matter of due process. ${ }^{216}$

\section{Statutory Preclusion}

The Supreme Court also has recognized that Congress has the authority to enact statutes that preclude otherwise justiciable and proper claims seeking specific constitutional relief and divert such claims into alternative and exclusive statutory or administrative enforcement regimes. One example, already mentioned, requires claimants seeking a refund for an unconstitutional federal tax to forgo a claim for specific relief and to seek an administrative refund remedy before suing the United States. ${ }^{217}$ Another was validated in Yakus $v$. United States, ${ }^{218}$ where the Court upheld legislation prohibiting a criminal defendant from seeking nullification of the law authorizing the prosecution where the defendant had already had an opportunity to challenge it in a prior administrative proceeding. ${ }^{219}$ More recently, in Elgin v. Department of the Treasury, ${ }^{220}$ the Court held that the federal Civil Service Reform Act ${ }^{221}$ provides the exclusive avenue to judicial review when a qualifying federal employee challenges an adverse employment action by arguing that the federal statute requiring the action is unconstitutional on its face. ${ }^{222}$ And in Smith v. Robinson, ${ }^{223}$ the Court held that the federal Education of the Handicapped $\mathrm{Act}^{224}$ provided the exclusive avenue for specific

216 See supra Part II.B.2.e and especially note 134 (explaining that specific remedies to enjoin the collection of an unconstitutional tax are frequently unavailable but that due process requires the provision of post-deprivation relief for unconstitutionally exacted taxes). Due process protects those seeking specific constitutional relief in a federal court from the double whammy of being told to seek a remedy elsewhere and then subsequently being told that a sovereign immunity doctrine makes the relief unavailable in the alternative forum. $C f$. Henry M. Hart, Jr., The Power of Congress to Limit the Jurisdiction of Federal Courts: An Exercise in Dialectic, 66 HARV. L. REV. 1362, 1366-70 (1953) (discussing this theoretical dilemma and opining that it would be unconstitutional to provide fewer than one bite at the constitutional apple).

217 See 26 U.S.C. $\S 7421$ (a) (2006) (precluding, with limited exceptions, any suit for the purpose of restraining the collection of any tax); United States v. Clintwood Elkhorn Mining Co., 128 S. Ct. 1511 (2008) (detailing how a taxpayer forced to pay an unlawful federal tax must seek a refund administratively before suing the government for a refund under the Tucker Act); see also supra notes 134 \& 137 and accompanying text.

218321 U.S. 414 (1944).

219 See id. at 443-48. For a discussion of Yakus and related cases and developments, including a note questioning whether the scheme upheld in Yakus would be constitutional absent the exigency of potential wartime inflation that was present in that case, see FALLON ET AL., HART AND WECHSLER, supra note 10, at 322-24.

220132 S. Ct. 2126 (2012).

2215 U.S.C. $\$ 1101$ et seq. (2006).

222 See 132 S. Ct. at $2132-40$.

223468 U.S. 992 (1984).

22420 U.S.C. $\S 1400$ et seq. (2006). The statute is now known as the Individuals with Disabilities Education Act. Id. $\S 1400($ a). 
relief from state and local officials under an equal protection claim that was virtually identical to an authorized statutory discrimination claim. ${ }^{225}$

But again, in each instance, the refusal to provide relief was rooted in an imperative of constitutional structure-i.e., the obligation under separation of powers concerns to honor congressional authority over remedies - and not in any expressed judicial concern about the effect that the relief sought might have on the public interest. Moreover, as with the judicial federalism doctrines, the Court has emphasized that an entirely different question would be presented if the preclusive and diversionary statute would have the effect of extinguishing the claim for a constitutional remedy altogether. ${ }^{226}$

\section{A LINK TO CONSTITUTIONALLY NECESSARY REMEDIES?}

Parts II and III have shown that the modern Supreme Court frequently exercises its normative and allocative discretion with respect to public interest balancing ${ }^{227}$ to formulate doctrines that require lower courts to withhold substitutionary constitutional relief and to leave wholly realized constitutional harms entirely without a remedy. They also have shown that, in contrast, the modern Court has treated the provision of specific constitutional remedies as routine, at least in cases where neither a judicial federalism nor a statutory preclusion doctrine applies. And even in these rather exceptional cases, the Court has expressed an unwillingness to countenance the withholding of remedies altogether; instead, it has emphasized that "serious constitutional concerns" would ensue if effective constitutional relief were unavailable in the alternative forums to which it has redirected some claimants pressing claims for specific relief. ${ }^{228}$

This final Part considers whether it is appropriate to draw from the described judicial behavior and statements any conclusions with respect to constitutionally necessary remedies. ${ }^{229}$ The topic is vast, and it will require another paper to fully explore whether the Court's willingness to engage in public interest balancing to withhold substitutionary, but not specific, constitutional remedies tracks a firm constitutional limit on judicial and congressional remedial prerogative ${ }^{230}$ But with that caveat, I believe that the differential treatment the Court accords such remedies with respect to public

225 See Smith, 468 U.S. at 1009-13. For an analysis of "proxy" enforcement of the Constitution in and through sub-constitutional regimes such as the examples just discussed, see John F. Preis, Constitutional Enforcement by Proxy, 95 VA. L. REV. 1663 (2009).

${ }^{226}$ See Smith, 468 U.S. at 1012 n.15 (emphasizing that the statutory remedy simply replaced the constitutional one and that " $[t]$ here is no issue here of Congress' ability to preclude the federal courts from granting a remedy for a constitutional deprivation").

227 See supra note 9.

228 See supra notes $215-16$ \& 226 and accompanying text.

229 For a summary of views on constitutionally necessary remedies, see supra notes 13-19 and accompanying text.

230 See Fallon, Jurisdiction-Stripping, supra note 10, at 1104-05 (opining that a comprehensive theory of constitutionally necessary remedies would likely require book-length treatment). 
interest balancing supports a two-part hypothesis. First, substitutionary constitutional remedies, while integral as a class to the proper functioning of our constitutional order, are properly regarded as individually contingent; such remedies are susceptible to legislative or judicial expansion, contraction, or replacement as the perceived public interest dictates. Second, specific constitutional remedies should be freely available for most justiciable and meritorious claims of constitutional right. Moreover, an effective constitutional remedy should be available from the alternative forum in those exceptional cases where claimants seeking specific relief are legitimately subject to diversion from federal court by a judicial federalism or statutory preclusion doctrine. And public interest balancing should not be employed in connection with claims for specific constitutional relief.

Obviously, the fact that the Supreme Court has engaged in public interest balancing to fashion doctrines requiring lower courts to withhold each type of substitutionary constitutional remedy goes a very long way towards refuting any descriptive claim that such remedies are constitutionally mandatory. Indeed, if one eschews purely normative or historical argument and seeks to develop a theory of constitutionally necessary remedies that rationalizes what the modern Court actually has done, one simply cannot maintain that a wholly realized violation of an individual constitutional right requires, ipso facto, a damages award, the subsequent exclusion of evidence, the reversal of a tainted conviction, or (most obviously) a structural reform injunction containing constitutionally extraneous provisions. The now well-established doctrines limiting the availability of these substitutionary constitutional remedies, discussed above, ${ }^{231}$ render such an argument difficult to sustain.

The argument that substitutionary constitutional remedies are constitutionally contingent also survives a shift in perspective from the descriptive to the normative. Certainly, the elimination without replacement of any one class of substitutionary constitutional remedy-let alone the wholesale elimination of all classes of such remedies - would raise a very serious constitutional issue. And just as certainly, the curtailment or elimination of certain substitutionary constitutional remedies would raise graver concerns than the curtailment or elimination of other substitutionary constitutional remedies; the necessity of any one type of substitutionary constitutional remedy surely should vary depending on the nature of the underlying violation that is alleged ${ }^{232}$ Even so, there are several reasons for treating substitutionary constitutional remedies - as a class - as inherently contingent and subject to legitimate alteration by Congress or the Supreme Court.

Substitutionary constitutional remedies are often and accurately described as species of sub-constitutional common law because they lack the textual and historical

231 See supra Part III.A.

232 See generally John C. Jeffries, Jr., Disaggregating Constitutional Torts, 110 Y ALE L.J. 259 (2000) (arguing persuasively that the granting and withholding of constitutional remedies ought to vary depending on the underlying claim and the underlying constitutional right asserted in support of the claim). 
pedigrees of their specific remedial counterparts. ${ }^{233}$ By their very nature, they fail to prevent or undo the constitutional harm to which they are responsive. ${ }^{234}$ They most frequently apply only to the wholly concluded discretionary actions of the many individuals who necessarily exercise government power in modern society; they typically are not available to ameliorate the unconstitutional legislative or executive policies or customs that are more readily attributed to a coordinated branch of the government than the unlawful act of a single government agent. ${ }^{235}$ And finally, they can visit very significant costs on members of the polity who employ or contract with the targeted defendant, including of course the symbolically potent release of the dangerous criminal by operation of the exclusionary rule "because the constable has blundered." ${ }^{\text {"236 }} \mathrm{In}$ view of all these things, it is an uphill battle to argue that courts always must issue a substitutionary constitutional remedy upon finding a wholly concluded invasion of an individual constitutional right, irrespective of the perceived effect such a remedy might have on the public interest.

Specific constitutional remedies, in contrast, present quite a different set of considerations. Specific constitutional remedies are far more closely tied to constitutional text and structure. Two such remedies - habeas corpus and just compensation for takings claims - are explicitly contemplated, ${ }^{237}$ and the rest are strongly implied, at least once one accepts the legitimacy of the anticipatory action for specific relief by a party with Article III standing. ${ }^{238}$ Moreover, and just as importantly, the enforcement of individual

233 See, e.g., Meltzer, supra note 26, at 29-34 (comparing Chapman with Bivens and arguing that both rules are at least partially sub-constitutional); Monaghan, supra note 24, at $200 \mathrm{n} .30$ (describing the Chapman harmless error rule as constitutional common law); Monaghan, supra note 23, at 3-10 (describing the exclusionary rule as example of constitutional common law); id. at 23-24 (describing the implied Bivens damages remedy as constitutional common law). Of all the recognized substitutionary constitutional remedies, it is perhaps hardest to envision the permissible elimination of a right to secure reversal of a criminal conviction tainted by constitutional error. But the Supreme Court has repeatedly stated that there is no constitutional right to an appeal. See Pennsylvania v. Finley, 481 U.S. 551, 555-56(1987) (quoting Ross v. Moffitt, 417 U.S. 600, 610-11 (1974)); Jones v. Barnes, 463 U.S. 745, 751 (1983); McKane v. Durston, 153 U.S. 684, 687 (1894). Moreover, no general right to appeal existed in colonial or English practice, in the states at the time of the Founding, or in the federal courts until 1891. See Meltzer, supra note 26, at 6 (collecting authority). In view of all this, it is difficult to claim that there is a constitutional right to secure post hoc reversal of a conviction infected by constitutional error.

234 Paul Gewirtz has argued that the law of remedies is by its nature "a jurisprudence of deficiency, of what is lost between declaring a right and implementing a remedy." Paul Gewirtz, Remedies and Resistance, 92 YALE L.J. 585, 587 (1983). Gerwitz's statements describe reality with respect to all remedies but apply with special force to substitutionary remedies.

235 See supra Part II.C.

${ }^{236}$ See People v. Defore, 150 N.E. 585, 587 (N.Y. 1926).

237 See supra Parts II.B.2.c-d.

238 There is broad agreement that nullification of unconstitutional laws by the subject of government enforcement actions is the quintessentially necessary constitutional remedy from an Article III court with the power of judicial review. See supra note 105 and accompanying text. 
rights through specific relief protects constitutional structure in much the same way that the enforcement of structure through the power of judicial review can protect individual rights. ${ }^{239}$ As already discussed, specific remedies tend to be available only in situations where the government action being challenged is undertaken pursuant to some "law"-i.e., some policy or custom directly attributable to one of the political branches of the federal and state governments. ${ }^{240}$ Thus, specific remedies reasonably may be seen as more essential than their substitutionary counterparts for keeping the coordinate federal branches and the states within constitutional boundaries at the lawmaking level.

One final point is also worth noting. The most comprehensive descriptive account of constitutionally necessary remedies to be found in the academic literature-an analysis provided by Professor Fallon in a recent Virginia Law Review article ${ }^{241}$-is entirely consistent with the hypothesis that this Part advances. Fallon begins by noting the primacy of Professor Henry Hart's observation that complaints about the preclusion of a particular remedy "can rarely be of constitutional dimension."242 But Fallon then observes that Hart, who wrote in 1953 before the explosion of substitutionary constitutional remedies and related doctrines that occurred during and after the Warren Court years, was troubled by the notion that constitutional remedies could be withheld altogether ${ }^{243}$ Fallon draws on this background to describe the theory of constitutionally necessary remedies that he and Professor Meltzer proposed in 1991-that there be a rebuttable presumption in favor of effective relief in all cases, and a sufficient scheme of remedies to keep government officials answerable to the demands of the Constitution ${ }^{244}$ - as being designed to harmonize modern doctrinal reality (in which constitutional remedies are often withheld) with Hart's claims about constitutional remedies. ${ }^{245}$

${ }^{239}$ See Nat'l Fed'n of Indep. Bus. v. Sebelius, 132 S. Ct. 2566, 2578 (2012) (citing New York v. United States, 505 U.S. 144, 181 (1992)) (describing how our federalist structure preserves individual liberties); see also id. ("By denying any one government complete jurisdiction over all the concerns of public life, federalism protects the liberty of the individual from arbitrary power." (quoting Bond v. United States, 131 S. Ct. 2355, 2364 (2011))).

${ }^{240}$ See supra Part II.C.

241 See Fallon, Jurisdiction-Stripping, supra note 10, at 1104-15. Fallon's account elaborates on the general theory of constitutionally necessary remedies he and Professor Meltzer initially proposed in 1991. See Fallon \& Meltzer, supra note 16, at 1787-91.

${ }^{242}$ Fallon, Jurisdiction-Stripping, supra note 10, at 1105 (quoting Hart, supra note 216, at 1366) (internal quotation marks omitted).

${ }^{243} I d$. at 1106 (observing that the question of whether constitutional remedies may be entirely withheld has never really been squarely presented because of " $[t]$ he multiplicity of remedies, and the fact that Congress has seldom if ever tried to take them all away" (quoting Hart, supra note 216 , at 1369)).

${ }^{244}$ See supra notes 17-19 and accompanying text (summarizing Fallon \& Meltzer, supra note 16 , at 1787-91).

${ }^{245}$ See Fallon, Jurisdiction-Stripping, supra note 10, at 1107-08. 
Turning to what the modern Court has said and done, Professor Fallon identifies five classes of constitutional remedies that should be regarded as constitutionally necessary. ${ }^{246}$ Interestingly, not one of these five classes contains any substitutionary constitutional remedy. Instead, the five classes largely describe the field of specific constitutional remedies discussed in Part II.B of this paper: (1) nullification of constitutionally invalid laws, ${ }^{247}(2)$ habeas corpus, ${ }^{248}(3)$ post-deprivation monetary remedies for coercive deprivations of property and liberty, ${ }^{249}(4)$ injunctive or similarly effective relief against ongoing deprivations of constitutional rights that would not be adequately compensable by damages, ${ }^{250}$ and (5) remedies for deprivations of "new property." 251 Thus, although he travels a different road, Fallon arrives at the same destination to which we are led by an examination of the Court's use of public interest balancing to withhold constitutional remedies.

\section{CONCLUSION}

The use of traditional law/equity terms to classify constitutional remedies can operate to obscure important truths about how modern courts behave in issuing and administering such remedies. It is far more useful to reclassify constitutional remedies in terms of how they function. Do they provide the original thing or condition to which the claimant was entitled? Or do they provide something else? If the former, they are specific; if the latter, they are substitutionary.

The adoption of a functional classification of constitutional remedies is clarifying. It reveals that the conventional account of our remedial tradition, which associates the discretionary withholding of remedies under public interest balancing only with the specific remedies typically issued in equity, has things entirely wrong with respect to constitutional remedies. In the context of constitutional remedies, the modern Supreme Court uses public interest balancing only to withhold the substitutionary remedies

\footnotetext{
246 See id. at 1108-15.

247 See id. at 1108.

${ }^{248}$ See id. at 1109.

249 See id. at 1109-11. Professor Fallon discusses the tax refund and takings cases under this heading. See id.

${ }^{250}$ See id. at 1111-13. In describing this class of remedies as encompassing only those claims for injunctive relief that would not be adequately compensated by damages, Professor Fallon nods to the traditional idea that injunctive relief will not lie where there is an adequate remedy at law. But in his discussion of the class, Fallon acknowledges that the modern Supreme Court has treated injunctive relief as routine since Brown v. Board of Education, 347 U.S. 483 (1954). See Fallon, Jurisdiction-Stripping, supra note 10, at 1112-13.

251 See Fallon, Jurisdiction-Stripping, supra note 10, at 1114-15. This class includes claims based on individual constitutional rights, such as equal protection or due process, arising from the government's distribution of statutorily created entitlements. See id. at 1114. Such claims are a subset of the claims seeking specific relief for ongoing or imminent constitutional violations discussed in Part II.B.2.b.
} 
usually provided at law. ${ }^{252}$ It does not use public interest balancing to withhold the specific relief typically administered in equity. ${ }^{253}$

Appreciation of this fact is highly useful in and of itself, but it also illuminates the complex topic of constitutionally necessary remedies. Any theory of constitutionally necessary remedies that seeks to rationalize what modern courts actually do must respond to this reality and consider whether the Supreme Court's behavior tracks a constitutional boundary. For the reasons stated above, I believe that it does.

252 See supra Part III.A.1.

${ }^{253}$ See supra Part III.B. 
